NBER WORKING PAPER SERIES

\title{
LOVE, MONEY, AND PARENTAL GOODS: DOES PARENTAL MATCHMAKING MATTER?
}

\author{
Fali Huang \\ Ginger Zhe Jin \\ Lixin Colin Xu \\ Working Paper 22586 \\ http://www.nber.org/papers/w22586 \\ NATIONAL BUREAU OF ECONOMIC RESEARCH \\ 1050 Massachusetts Avenue \\ Cambridge, MA 02138 \\ September 2016
}

We wish to thank Yuyu Chen, Steve Cheung, William Evans, James Heckman, Bert Hoffman, Yi Lu, Vijayendra Rao, Seth Sanders, Mary Shirley, Jeffrey Smith, Liming Wang, Dali Yang, and participants at the Chicago-Renmin symposium on family and labor economics at the University of Chicago, the symposium of the 80th birthday of Steven Cheung at Shenzhen, U. of Maryland workshop, the AEA meetings, the PAA conference, and the Asian Conference on Applied MicroEconomics/Econometrics at Tokyo for constructive comment and suggestions. We are especially grateful to the late Gary Becker for his detailed comments at the Chicago-Remin symposium in which we presented an earlier version of a related paper. He encouragedus to consider the issues from the perspective of parents and old age support. This paper would not exist without his encouragement and comments. We also thank the excellent research assistance from Lixin Tang. Huang gratefully acknowledges the financial support of SMU Research Grant 10-C244SMU-002. The views expressed here do not implicate the World Bank or the countries that it represents. Part of the paper was revised when Jin visits the Federal Trade Commission. Any view expressed here does not represent the view of the Commission, any of its commissioners, or the National Bureau of Economic Research.

NBER working papers are circulated for discussion and comment purposes. They have not been peer-reviewed or been subject to the review by the NBER Board of Directors that accompanies official NBER publications.

(C) 2016 by Fali Huang, Ginger Zhe Jin, and Lixin Colin Xu. All rights reserved. Short sections of text, not to exceed two paragraphs, may be quoted without explicit permission provided that full credit, including $\odot$ notice, is given to the source. 
Love, Money, and Parental Goods: Does Parental Matchmaking Matter?

Fali Huang, Ginger Zhe Jin, and Lixin Colin Xu

NBER Working Paper No. 22586

September 2016

JEL No. D82,D83,J12

\begin{abstract}
$\underline{\text { ABSTRACT }}$
While parental matchmaking has been widespread throughout history and across countries, we know little about the relationship between parental matchmaking and marriage outcomes. Does parental involvement in matchmaking help ensure their needs are better taken care of by married children?This paper finds supportive evidence using a survey of Chinese couples. In particular, parental involvement in matchmaking is associated with having a more submissive wife, a greater number of children, a higher likelihood of having any male children, and a stronger belief of the husband in providing old age support to his parents. These benefits, however, are achieved at the cost of less marital harmony within the couple and lower market income of the wife. The results render support to and extend the findings of Becker, Murphy and Spenkuch (2015) where parents meddle with children's preferences to ensure their commitment to providing parental goods such as old age support.
\end{abstract}

Fali Huang

Singapore Management University

flhuang@ @mu.edu.sg

Ginger Zhe Jin

University of Maryland

Department of Economics

3115F Tydings Hall

College Park, MD 20742-7211

and NBER

jin@econ.umd.edu
Lixin Colin Xu

MC 3-420, World Bank

1818 H Street, N.W.

Washington, DC 20433

lxu1@worldbank.org 
JEL: J12, D82, D83.

Keywords: Marriage, Matchmaking, Parental Matchmaking, China, Agency

Cost, Old Age Support, Parental Goods, Preference Manipulation, Endogenous Institutions.

\section{Introduction}

Since the pioneering work of Becker $(1973,1974)$, marriage formation is often modeled as a matching process where males and females meet each other randomly or are assisted by commercial agents (Weiss, 1997). This approach ignores a unique feature of marriage matching: marriage is not simply of two individuals forming a new family; rather, it directly affects the welfare of their parents.

Many "goods" produced by the couple - including their labor market income, household goods and services, children, and old age support - can be sharable and beneficial to parents. Old age support is a prominent example. Throughout history and in many developing countries today, old age support depends critically on children (e.g., Cheung, 1972; Davidson and Ekelund, 1997; Anderson, 2003). How can parents ensure that old age support will be provided by children after they grow up? In traditional China, such provision was ensured by parental ownership of children and the cultivation of filial piety (i.e., children submissiveness to parents) (Cheung, 1972). In the modern world, Becker, Murphy and Spenkuch (2015) (BMS 2015 hereafter) argue that, when old age support is mainly provided by adult children, parents will put in resources to meddle with children's preferences and make them more altruistic towards parents.

In this paper we show that, by having a say at the stage of spouse searching, parents may be able to get a favorable provision of old age support and other parental goods from their children. This is achieved by nudging the potential spouse choice towards what the parents prefer in light of parental goods to be provided by the couple.

Parental goods refer to market or household goods and services directly consumed by parents, either through household public goods or direct expenditure on parents. For example, married children with high labor market incomes may give parents high income transfer in various forms. Alternatively, children with a low market income may spend more time providing household-produced goods and services (including companionship). A pleasant personality of the spouse often becomes crucial in providing essential emotional and social support for old parents. The presence of a large number of grandchildren may also be considered as an essential contribution of adult children to parental goods, and in particular, having at least one male grandchild can offer extra boost to their satisfaction. As put by 
Mencius, a key Chinese philosopher from 372-289 B.C., "of the three deeds disrespectful to parents, the worst is to bear no children."

Parental goods enter the utility function differently from the indirect component of the utility through parental altruism towards children. For example, altruistic parents may derive utility from having a happily married adult child, but the emotional attraction within the couple is not a parental good. Indeed, parental matchmaking may involve a trade-off between children's welfare and parental goods. In particular, parents who help in matchmaking expect to have a long-term relationship with the couple, and these future interactions may distort the incentive of matchmaking and, therefore, affect the matching outcomes.

Consider a son who chooses between self and parental match-making. His satisfaction with his spouse depends on expected marriage outcomes, including the couple's joint income, household production, and love. In contrast, parents obtain a spillover from the couple's market and household production, and being altruistic, they also obtain an altruistic component originating from the son's welfare from the marriage.

Conflict of interest arises from the parents' keen interest in the couple's market and household production. Parents who expect to receive parental goods from their son after his marriage may care less about how attractive his wife is to him and how harmonious the couple's married life will be, but more about how able she is in contributing to family wealth, offspring, old age support and other household production (Cheung, 1972). Parents may also care more about the compatibility of the daughter-in-law's preference with their needs, and therefore weigh their harmony with the daughter-in-law more heavily than the harmony between the future couple. As a result, the best wife candidate in the eyes of parents probably differs from what is optimal to the son, even though parents are altruistic and care about the son's welfare. Thus, parental matchmaking carries an agency cost for the son, but it is beneficial for parental welfare.

Without search costs, the son would prefer self search to avoid the agency cost in parental matchmaking. However, parents and children differ in search costs. On the one hand, parents may face higher search costs for love within the potential couple than the son. On the other hand, parents can have a wide access to potential candidates via their own social networks. Parental search can be a greater advantage if parents are better at judging the candidate's character and earning ability. Thus, despite the agency costs of parental matching, it is sometimes optimal for the son to choose parental matchmaking because of the saving in search costs.

We incorporate both agency costs and search costs into a theoretical framework, and derive several testable implications. First, love in a marriage should be lower for parentinvolved matches than for self-matches. This is because parents value more than their son 
the monetary and household production components of his marriage, and they have a higher marginal cost in assessing love within the couple. Due to the agency cost, the overall marriage gain to the son, measured by love, income and household production but excluding search cost, would be lower under parent-involved matches than self matches. However, the sharable part of the marriage outcome could be lower or higher under parental matchmaking. It could be higher because parents put more emphasis on sharable market and household production than on love, and the wife who is picked by parents therefore tends to have a higher ability to contribute to the sharable productions. It could be lower when parents overemphasize goods produced within the household and the preservation of the old social structure at the expense of market productivity. In this case, the couple's market income may be lower in parent-involved matches, but key elements for household production such as the number of children, willingness to provide old age support, and the submissiveness of the wife would increase.

We take these predictions to a sample of 6,334 couples in 1991 from seven Chinese provinces. In the sample, $48 \%$ of rural couples and $14.5 \%$ of urban couples were married by parent-involved matchmaking; the rest by either self search or friend introduction (both of which are referred to as self match). Comparison across parental and self matching largely supports our theoretical predictions. In the full sample, parent-involved matches yield lower marital harmony and lower couple income, but parent matches are more likely to have submissive wives, less labor market participation of wives, lower wife income, a greater number of children, a higher likelihood of having a boy, and a stronger belief of the husband in providing old age support to his parents. In particular, when we allow parental matchmaking to have different effects on couple incomes across urban and rural areas, its effect is positive for urban couples (as in Huang et al., 2012) but negative for rural couples. Many household outcomes examined in this paper - fertility, old age support, and wife submissiveness - are more important in rural than urban areas, because rural areas have fewer job market opportunities, provide less social support for the elderly, offer less market provision for services, and hold stronger beliefs on traditional family values. So rural parents may emphasize women's contribution within the household more than market earnings.

Our work extends BMS (2015) in a few ways. BMS (2015) suggests that parents have incentives to meddle with children's preferences in order to ensure their commitment to providing old age support. Instead of using human capital investment as a tool to make children more altruistic, we argue that parents can exert their influence even after the son has grown up by actively involving in the searching process and the final selection of the potential daughter-in-law. In this sense, we take the son's schooling as predetermined while focus on parents' incentive in matchmaking. Moreover, we extend parental consideration 
from old age support to all sorts of parental goods that could be beneficial to parents. Because different parental goods may require different traits of the daughter-in-law, it is an interesting empirical question to assess how parental preference and the social environment that shapes this preference affect parental involvement in matchmaking.

In addition to extending BMS (2015) and Huang et al. (2012), this paper contributes to the marriage literature by highlighting the economic trade-offs in parental matchmaking. Unlike the classical focus on the effects of sex ratio (Angrist, 2002), divorce law (Chiappori, 2002), or educational composition on marriage outcomes, we show that the institutional details of how the match is accomplished in the first place also have important implications. ${ }^{1}$ In a related paper, Edlund and Lagerlof (2006) show that the shift from parental to individual consent in marriage allows the young couple, instead of their parents, to receive the bride price and thus facilitates economic growth. We differ in that our focus is not on who controls financial resources in a marriage, but on who has more influence on the the choice of spouse. The trade-off between love and money has also been explored by Fernandez et al. (2005), but their perspective is of marriage sorting on skills and its relationship with income inequality; they do not discuss matchmaking methods. ${ }^{2}$ Our paper is also related to Cheung (1972), who argues that many traditional Chinese family practices, ${ }^{3}$ including marriage patterns, are shaped by parental considerations to maximize family wealth, and that filial piety is an endogenous belief that is conducive to the purpose of family wealth maximization. That paper does not focus on the effect of matchmaking methods; neither does it offer econometric evidence. Finally, our paper is related to the literature of inter-generational relationship and old age support. Researchers have explored how inter-generational relationships affect old age support (see, for instance, Ikkink, Tilburg and Knipscheer, 1999; Hoff, 2007). However, none has explored the role that matchmaking methods play in facilitating old age support.

The rest of the paper is organized as follows. Section 2 describes the theoretical insights, Section 3 summarizes the data, and Section 4 presents the empirical results. A brief conclusion is offered in Section 5.

\section{Theoretical Framework and Empirical Identification}

In this section, we first present an agency model of parental matchmaking and then interpret it in the context of parental goods. The last subsection discusses empirical implications

\footnotetext{
${ }^{1}$ Some other papers related to marriage include Zhang and Chan (1999), Foster and Rosenzweig (2000), Chiappori et al. (2002), Suen, Chan and Zhang (2003), and Huang et al. (2009).

${ }^{2}$ See also Blood (1967) for descriptive analysis of love and arranged marriages.

${ }^{3}$ China-specific papers and books on marriage include Chao (1983), Xu and Whyte (1990), Cohen (1992), and Zimmer and Kwong (2003), none of which examines how parental matchmaking affects marriage outcomes and how considerations of old age support affect these effects.
} 
and how we plan to test them with data.

\subsection{Agency model of parental matching}

Consider the marital decision of a young man, who has finished schooling and started working to earn a living. The search process for a potential wife can either be conducted directly by his parents or by himself. The process that yields a higher net expected utility to him will be implemented. This setup is meant to capture the current practice in China, where marriage in general cannot be forced upon a child by parents, and males are usually the ones who initiate and propose marriage. ${ }^{4}$

\subsubsection{Basic Set up}

An individual's benefit from marriage can be categorized into two dimensions: one is the economic gain from joint household production and the other is emotional support from the spouse. The total benefit is affected not only by the characteristics of husband and wife, but also by their matching quality.

Let $h_{m} \geq 0$ denote the young man's human capital level, which affects his earning and his intra-household productivity. The human capital may capture, for example, his character, innate ability, years of schooling, communication skills, and so on. Similarly, let $h_{f} \geq 0$ denote his potential wife's human capital level. Combined, $h_{m}$ and $h_{f}$ determine the total marriage gains $f\left(h_{f}, h_{m}\right)$, which reflects both the couple's household production output and joint income earned from markets. We assume $f(0,0)>0, f_{i}>0, f_{i j}>0$, and $f_{i i} \leq 0$ for $i, j \in\{1,2\}$.

Another key element in marriage is match quality, denoted by $\alpha$ which is idiosyncratic to the couple and not readily observed by others; it can be interpreted as love or attraction between two persons, which is often unpredictable based on commonly observed characteristics. This implies that $\alpha$ can be treated as uncorrelated with $h_{f}$. Given our assumption that marriage is always implemented with mutual consent by the young couple, the emotional output of marriage can be normalized as positive and $\alpha>0$ is assumed. ${ }^{5}$

For a young man with $h_{m}$, the overall gain from marrying a wife with $h_{f}$ and $\alpha$ is $(\beta+\alpha) f\left(h_{f}, h_{m}\right)$, where $\beta>0$. The parameter $\beta$ captures the husband's share of material gain from the marriage, while $\alpha$ captures the degree of emotional benefit.

\footnotetext{
${ }^{4}$ In modern China where our data are from, the son's consent is necessary for parents to be involved in wife searching and parents can no longer force the son to accept their choice of daughter in law. The relevant evidence from the data is discussed in Section 3.2. Having said that, modeling matchmaking means as the choice of the son or the choice of his parents will yield the same qualitative results. A similar model can also be used to study the search process of a young woman.

${ }^{5}$ This assumption is for simplicity only, as the same results can be derived for the case with $\alpha \leq 0$.
} 
The parents' gain from their son being married to a wife with characteristics $\left(\alpha, h_{f}\right)$ also contains two parts: one is the public good component $f\left(h_{f}, h_{m}\right)$ that generates a utility of $\gamma \cdot f\left(h_{f}, h_{m}\right)$, which corresponds to all sorts of parental goods; the other is the altruistic component $\delta(\beta+\alpha) f\left(h_{f}, h_{m}\right)$ because they care about the welfare of their son, where $\gamma>0$ and $\delta \in(0,1)$. Since the love $\alpha$ between the husband and wife is by definition consumed privately by the couple themselves, it does not affect the parents' welfare directly. The wife's characteristics that may affect the whole family, such as pleasant personality and beauty, are already indicated by the wife's human capital $h_{f}$, which as mentioned earlier is broadly defined and not restricted to formal schooling. ${ }^{6}$

Marital search is costly. If searching himself, the son has to bear the search cost, which is $\eta_{m} c\left(\alpha, h_{f}, h_{m}\right)>0$, where $\eta_{m}, c_{1}, c_{2}>0$ and $c_{3}, c_{31}, c_{32}<0$. This means that it is more costly for a man with a given $h_{m}$ to find and persuade a woman with better quality (with higher $\alpha$ or $h_{f}$ ) to become his wife, and the search cost for a wife of a given quality is lower if the man's $h_{m}$ is higher. The parameter $\eta_{m}$ denotes the effect of some common elements on the search cost by oneself for all individuals in a marriage market, and is thus not dependent on idiosyncratic conditions of searching.

If the marriage is through parental search, parents will bear the search cost, which depends on how intelligent they are in assessing $\alpha$ and how well they are connected with relevant social networks that have access to potential candidates. The parents' degree of competence in this matter is denoted by $h_{p} \geq 0$. The parental search cost is $\eta_{p} s\left(\alpha, h_{f}, h_{p}\right)>0$, where $\eta_{p}, s_{1}, s_{2}>0$ and $s_{3}, s_{31}, s_{32}<0$. Similar to $\eta_{m}$, the parameter $\eta_{p}$ denotes some common factor that affects the cost of searching by all parents. To capture the idea that the match quality $\alpha$ is couple idiosyncratic, we assume that, in order to achieve the same level of $\alpha$, the parents' search cost cannot be too low compared with the direct search by their son, i.e., $\eta_{p} s_{1} \geq \delta \eta_{m} c_{1}$ for any given $h_{m}, h_{f}$, and $h_{p}$.

A few comments on the model assumptions are in order. We assume the emotional component of marital output $(\alpha)$ enters multiplicatively with the total output of the couple $\left(f\left(h_{f}, h_{m}\right)\right)$, in order to capture the possibility that marital harmony may affect the productivity of highly educated individuals to a greater extent, as creativity and precision in job performance are relatively more easily reduced by emotional disturbances than manual labor. In this sense, the emotional component and human capital are complements, which is similar to a pattern in the business world where matching quality matters more for firms with high-skilled working environment. The multiplicative assumption is not essential to our main results; we have double checked the alternative setup where they are additive, and all

\footnotetext{
${ }^{6}$ Parents may have other gains from doing matchmaking than the elements already shown in the model; as long as these concerns are not identical with those of their children, our main results should hold.
} 
predictions go through. If we do not adopt the multiplicative assumption, the assumption $c_{31}<0$ becomes essential to the sorting result presented below. In other words, $c_{31}<0$ holds if highly educated people have a greater social circle and hence more opportunities to meet a potential spouse, or if they also have better capabilities to convince the spouse candidate to marry them eventually. So even though their salary and hence opportunity cost per hour is high, the fact that they may spend much less time in wooing the potential spouse is likely to reduce their overall searching cost. For example, the potential cost for a Forrest Gump to convince an attractive woman to marry him can be much higher than that for a Bill Gates. In short, for the model to carry through, we need either the multiplicative assumption or the assumption of $c_{31}$ being negative, but not necessarily both.

Another key assumption lies in the non-transferability of search cost. The cost in finding a potential spouse, though containing a monetary and material component that is transferable, has a substantial part that is difficult to transfer between parents and children. For example, one often gets to know a potential spouse through social gatherings and events, and this means that the son or the parents have to participate themselves by spending time, effort, and other expenditure that are not easily transferable. And usually such social occasions are organized around their own social networks such as friends and coworkers, which are simply not accessible by others in the family. The time, effort, and gifts required in maintaining ongoing social networks and events are not easily transferable. If the son conducts the search himself, he has to spend his own effort and incur expenditures that can't simply be compensated by his parents. Similarly, if parents conduct the search, they will rely on their friends and relatives with whom the son may not be familiar. The model captures this nontransferable part while leaving the transferable part as a common component that will drop out in search cost comparison.

\subsubsection{The Son's Optimal Choice of Search Methods}

The son decides whether to search for his marriage partner himself or to delegate the search to his parents. If he searches himself, his objective function is

$$
U^{*} \equiv \max _{\alpha, h_{f}}(\beta+\alpha) f\left(h_{f}, h_{m}\right)-\eta_{m} c\left(\alpha, h_{f}, h_{m}\right)
$$

The corresponding optimal choices of his potential wife's characteristics that result from searching by himself are denoted by $\alpha^{*}$ and $h_{f}^{*}$, which are characterized by the following first order conditions

$$
f\left(h_{f}^{*}, h_{m}\right)-\eta_{m} c_{1}\left(\alpha^{*}, h_{f}^{*}, h_{m}\right)=0
$$




$$
\left(\beta+\alpha^{*}\right) f_{1}\left(h_{f}^{*}, h_{m}\right)-\eta_{m} c_{2}\left(\alpha^{*}, h_{f}^{*}, h_{m}\right)=0 .
$$

If his parents manage the search, their objective function is

$$
\widetilde{U} \equiv \max _{\alpha, h_{f}}[\gamma+\delta(\beta+\alpha)] f\left(h_{f}, h_{m}\right)-\eta_{p} s\left(\alpha, h_{f}, h_{p}\right),
$$

where the corresponding optimal choices are denoted by $\alpha^{* *}$ and $h_{f}^{* *}$. The necessary conditions that characterize $\alpha^{* *}$ and $h_{f}^{* *}$ are

$$
\begin{aligned}
\delta f\left(h_{f}^{* *}, h_{m}\right)-\eta_{p} s_{1}\left(\alpha^{* *}, h_{f}^{* *}, h_{p}\right) & =0, \\
{\left[\gamma+\delta\left(\beta+\alpha^{* *}\right)\right] f_{1}\left(h_{f}^{* *}, h_{m}\right)-\eta_{p} s_{2}\left(\alpha^{* *}, h_{f}^{* *}, h_{p}\right) } & =0 .
\end{aligned}
$$

It is easy to see that in general the optimal wives are different between these two search processes.

Then the son's choice problem is $\max \left\{U^{*} ; U^{* *}\right\}$, where

$$
U^{*} \equiv\left(\beta+\alpha^{*}\right) f\left(h_{f}^{*}, h_{m}\right)-\eta_{m} c\left(\alpha^{*}, h_{f}^{*}, h_{m}\right) ; U^{* *} \equiv\left(\beta+\alpha^{* *}\right) f\left(h_{f}^{* *}, h_{m}\right),
$$

and the second term is the son's net utility when his parents do the search for him. Searching by himself will prevail if $U^{*} \geq U^{* *}$, while his parents will be delegated to do the search if the opposite $U^{*}<U^{* *}$ is true. ${ }^{7}$ The main implications of the optimal solution to this problem are summarized by the following propositions (see Appendix A for proof):

Proposition1: Effects of Parental Matchmaking: The emotional output and the overall marriage gain to the son are lower under parental involvement, i.e., $\alpha^{*} f\left(h_{f}^{*}, h_{m}\right)>$ $\alpha^{* *} f\left(h_{f}^{* *}, h_{m}\right)$ and $\left(\beta+\alpha^{*}\right) f\left(h_{f}^{*}, h_{m}\right) \geq\left(\beta+\alpha^{* *}\right) f\left(h_{f}^{* *}, h_{m}\right)$ hold, respectively. But it is possible that the couple's joint household production is higher, i.e., $f\left(h_{f}^{*}, h_{m}\right) \leq f\left(h_{f}^{* *}, h_{m}\right)$ may be true.

Proposition2: Adverse Selection of the Son: There exists a unique threshold value $h_{m}^{\#}$ of the son's human capital level such that he will choose to search for a marriage partner himself if $h_{m} \geq h_{m}^{\#}$, while delegate his parents to do the search for him if $h_{m}<h_{m}^{\#}$. The threshold $h_{m}^{\#}$ increases with $h_{p}, \gamma$ and $\eta_{m}$.

Proposition 3 : Positive Selection of Parents: There exists a unique threshold value $h_{p}^{\#}$ of the parents' competence level such that they will be delegated to do the search iff $h_{p}>h_{p}^{\#}$, where $h_{p}^{\#}$ increases with $h_{m}$ but decreases with $\gamma$ and $\eta_{m}$.

\footnotetext{
${ }^{7}$ If parents can arrange the marriage without consent from the son, as is the case in traditional society, the parents are the final decision maker and their objective function would be $\max \left\{\left[\gamma+\delta\left(\beta+\alpha^{*}\right)\right] f\left(h_{f}^{*}, h_{m}\right) ;[\gamma+\right.$ $\left.\left.\delta\left(\beta+\alpha^{* *}\right)\right] f\left(h_{f}^{* *}, h_{m}\right)-\eta_{p} s\left(\alpha^{* *}, h_{f}^{* *}, h_{p}\right)\right\}$.
} 
These propositions suggest that the effects of parental involvement in marriage search can be different for the two dimensions of marriage output: it is always negative for the emotional output, which is driven by the fact that the matching quality - love $\alpha$ - is idiosyncratic to the couple and thus not easily observed or shared by others; the effect on the sharable output, however, can be either negative or positive. The reason for a positive effect is that the household output can be shared among family members and thus parents have more incentives to care about the potential wife's human capital. On the other hand, parental involvement could have a negative effect on the economic output and is still an optimal choice from the son's perspective if parental matchmaking leads to substantial savings in search cost.

Propositions 1-3 also suggest that parental involvement in marital search is endogenous to individual attributes. It is more likely to happen when the son's human capital level $h_{m}$ is lower or the searching cost $\eta_{m}$ is higher, or when his parents benefit more from parental goods (when $\gamma$ is higher) and have lower searching costs (when $h_{p}$ is higher and $\eta_{p}$ is lower). In other words, in a given marriage market, there are two sources of self-selection in the choice of marital search methods: one is from the son and the other is from the parents; a young man with a lower human capital, or with parents that are more capable or more motivated is more likely to rely on parental search.

Figure 1 illustrates the positive relationship between $h_{m}^{\#}$ and $h_{p}^{\#}$ and how their combination affects the endogenous choice of marital searching methods. In the graph, a young man with human capital $h_{m}^{\prime}$ and parents' effectiveness $h_{p}^{\prime}$, for example, will optimally choose to rely on his parents to search for a potential wife because his human capital is lower than the threshold level $h_{m}^{\#}$ corresponding to his parents' effectiveness $h_{p}^{\prime}$. This choice can also be understood from the alternative perspective: given his human capital level $h_{m}^{\prime}$, his parents are competent enough ( ince $h_{p}^{\prime}$ is higher than the corresponding threshold level $h_{p}^{\#}$ ) to find a good wife for him so that he does not bother to search by himself.

\subsection{Parental Goods Concerns In Spouse Selection}

The above agency model is based on the child's perspective, that is, it is his decision to choose self search or parental search. In this subsection, we interpret the model from the parents' perspective, especially in light of the parental goods they expect to obtain from the son's marriage.

In the scenario where the son entrusts the parents to do the marital search for him, what would be the parents' deliberations? Since parental goods may include both financial 
support and various non-financial home services from the married couple, attributes that can contribute to these production abilities, for example schooling for labor income and submissiveness for home services, will be favored under parental matchmaking. Parental deliberations become complicated if different types of parental goods require conflicting traits of the daughter-in-law. For example, bearing more children and doing more household chores often require the daughter-in-law to devote less time and effort to her career outside home. This trade-off is especially pronounced if the market is not developed well enough to provide household services at an affordable price. In that situation, which applies to many rural or economically less developed urban areas in China, parents may prefer a homeoriented, submissive daughter-in-law to someone else who is highly educated and careerdriven. Conversely, in large cities, the market may offer women more job opportunities and allow them to use labor market income to purchase food preparation, child care, and old age support from the market. The substitutability between labor market income and household service could induce parents to prefer a daughter-in-law with labor market skills at the expense of domesticity.

Fertility choice entails a special note. Though China has adopted the one-child policy since early 1980s, enforcement has been looser in rural areas. One reason is that rural labor is an important input for agricultural production, and without access to pension and health insurance, having a greater number of children is an important way to ensure old age support. Having at least one boy is especially important because a woman usually moves out of her own home and marries into her husband's family (Cheung, 1972). Even if the couple live on their own, they often live closer to the husband's parents, which explains why it is often the husband's parents who finance and build a new home for the newly wed couple. Traditional family values also require the couple to produce household services for the husband's parents and raise offspring who carry the husband's last name. For the same reason, traditionally only sons can inherit parents' property (Cheung, 1972). This tradition has faded away in large cities, but it still persists in rural and less developed areas. Furthermore, enforcing the one-child policy is more difficult in rural areas: while urban employers, especially state-owned enterprises and government units, can credibly threaten to demote, fine, or even fire those who attempt to have more than one child, such threats are not credible in rural areas. Thus, urban residents have little choice in the number or gender of children, but rural residents, if they want, can have more children than urban couples.

In short, in rural and less developed areas, the lack of government support for the elderly, the missing market for household services, and traditional family values will all motivate parents to demand a daughter-in-law who is more home-oriented and willing to raise at least one boy. In contrast, with less freedom in fertility, parents in more developed urban areas may 
resort to other means to ensure parental goods from their children, for example, aiming for higher education and higher couple income, even if that means less adherence to traditional values. $^{8}$ We thus expect more parental matchmaking in rural and less-developed areas, and such parental matchmaking should have a positive effect on the number of children, the likelihood of having at least one boy, and the submissiveness of the daughter-in-law.

Tying back to our theoretical model, a greater reliance on adult children for parental goods can be interpreted as parents putting more weight on the couple's sharable production relative to the son's welfare (i.e. higher $\gamma$ ). This implies greater agency cost under parental matching, as the wife candidates filtered by parents will demonstrate more attributes preferable by the parents for their consumption of parental goods $\left(\partial h_{f}^{* *} / \partial \gamma>0\right.$ mathematically).

If there are multiple parental goods and some parental goods are more crucially dependent on the couple than on the market, we can extend the model to include two sets of couple output (e.g. $f_{1}\left(h_{f}, h_{m}\right)$ for children and household service and $f_{2}\left(h_{f}, h_{m}\right)$ for labor market income) and allow parents to put more weight on one set than the other (e.g. $\gamma_{1}>\gamma_{2}$ ). In that case, parents will be more eager to look for a daughter-in-law who has favorable traits to deliver $f_{1}$ even if that implies less $f_{2}$.

So far we assume that the son cares only about his own welfare while parents are altruistic, following the standard assumption in Becker's Rotten Kids Theorem (Becker, 1981). BMS (2015) argue that parents have incentives to manipulate the son's preference when he was young so that he is more altruistic towards the parents' old age support when he grows up. This is consistent with the traditional values of Chinese families such as filial piety, which emphasizes that it is the son's duty to continue the surname by having children (especially boys), to be submissive to parents in general, and to take care of parents when they are old (Cheung, 1972). If the son's altruism is incorporated into our model, the son's preference will be more aligned with the parent's preference (e.g. allow $\beta$ to increase with $\gamma$ ). Not only does this reduce the agency cost of parental matchmaking (thus leading to more parental matchmaking), but it also encourages the son to choose a wife closer to the parents' preferences even if he decides to search by himself. BMS (2015) thus reconfigure the forces

\footnotetext{
${ }^{8}$ There are other factors to consider when discussing the effect of parental matchmaking on the number of children. Parents may view too many children as competition for the limited resources that the couple have. In other words, what grandchildren have, the grandparents have not. On the other hand, grandparents tend to enjoy the companion and even household production from grandchildren (e.g., fetching water where there is no indoor water), and this would result in a positive relationship between parental matchmaking and the number of children for the couple. The overall effect of parental matchmaking on the number of children may therefore be ambiguous. However, since children are less costly to raise in rural areas due to inter-generational cohabitation, the competition effect should be weaker in rural areas, again pushing for a more positive and pronounced relationship between parental matchmaking and the number of children in rural areas.
} 
underlying the costs and benefits of parental matchmaking so that the benefits now loom larger, and parents' demand for certain traits - say, submissiveness of the daughter-in-law and her willingness to raise at least one boy - is more likely to win out in the end. It also renders the son more willing to delegate the search to parents. However, allowing the parents to instill in their son an altruistic feeling towards them only mitigates the agency cost in parental matchmaking; as long as there is a wedge between the son and his parents' utility functions, our main results hold.

\subsection{Identification Issues}

We have argued that some conflict of interest may arise between parents and son because parents rely on their married son for sharable household production, but love is largely private consumption within the couple. ${ }^{9}$ This conflict of interest, combined with search cost in the marriage market, leads to an interesting relationship among parental matchmaking, husband's belief about old age support, wife characteristics, and marriage outcomes such as love, joint couple income, wife's labor participation status, and the number of children. The main insight is that parents involved in matchmaking prefer a wife good at providing sharable production, even if such preferences lead to less love within the couple. However, a challenge to the test of this prediction is the son's endogenous choice of the matchmaking method. In particular, the choice of search method may not only be affected by random elements, but also by the son's and his parents' characteristics as reflected by the adverse and positive selection problems in the above propositions.

If we can perfectly control parents' characteristics $\left(h_{p}, \gamma\right)$, then the average marital quality of husbands with parental involvement must be lower than others even when their wives are of the same quality because the husbands in the parent-matched group have lower human capital $\left(h_{m}<h_{m}^{\#}\right)$; this is the adverse selection effect of sons. In contrast, when the husband's characteristics are fully controlled, those with parental involvement must have had more competent parents $\left(h_{p}>h_{p}^{\#}\right)$ with respect to searching, which implies that their wife's overall quality, especially their human capital level $h_{f}^{* *}$, may be higher than others', and hence their marital quality may also be higher; this is the positive selection effect of parents. Thus, without properly accounting for these two sources of the endogeneity problem, the OLS estimated coefficient of parental matchmaking can be either higher or lower than the true effect, depending on which selection issue is dominant.

Our approach to address this challenge is to use instrumental variables that affect the

\footnotetext{
${ }^{9}$ That love is a private good is nicely illustrated by an episode of Seinfeld. Jerry and Elaine, once lovers and then friends for a long time, became lovers again. Witnessing Jerry and Elaine's intimate behavior, Kramer, Jerry's old friend and neighbor, blurts out, "I liked you two so much more when you were friends!"
} 
choice of search method but not wife characteristics and marital outcomes directly. The first instrument derives from social norms. Consider two identical marriage markets A and B that are mutually exclusive. Due to some exogenous shocks, the threshold level of the son's human capital $h_{m}^{\#}$, a function of parents' characteristics $h_{p}$, shifts down in market A but not in B. This can be achieved in the model, for example, by a lower $\eta_{m}$, which affects the search costs of all individuals in a marriage market. As shown in Figure 1, this downward shift in market $\mathrm{A}$ will induce a group of young men who are between the new and old threshold curves to change their search method from parental involvement to self search. As a result, identical individuals make different choices: those in market $\mathrm{B}$ have parental involvement, while those in market A adopt self-search. Comparing their difference in wife characteristics and marital outcomes will filter out the endogeneity in the choice of search method driven by the son or the parents' individual characteristics.

Empirically, for a husband born in year $t$, we construct the instrument for his choice of parental matchmaking as the percent of other husbands of similar ages in the same market who chose parental matchmaking. Here we define a market by the interaction of province dummy and rural dummy. A similar age cohort is defined as those born in the same year or one to three years earlier. Admittedly, this market-level instrument may capture local culture and tradition that affect people's choice of spouse and style of married life. Unfortunately, such culture and tradition evolve slowly, so that the main variations in our instrumental variable are cross-sectional. This implies that we cannot include provincial fixed effects without swamping the power of instrument, but we do control for average income and average schooling at the district level in urban areas and the township level in rural areas. ${ }^{10}$ In this sense, our instrument is good at filtering out individual-level selections as articulated in the above propositions, but it may pick up unobserved local culture and tradition independent of average income or schooling in local city/township.

In particular, we estimate the following specification:

$$
Y_{i m}=\alpha_{0}+\beta_{1} \cdot \text { ParentMatched }_{i m}+\beta_{2} \cdot Z_{i m}+\beta_{3} \cdot Z_{m}+\epsilon_{i}
$$

where for husband $i$ in market $m, Y_{i m}$ denotes marital outcomes, wife characteristics, and husband $i$ 's belief in old age support; $Z_{i m}$ denotes husband's observable characteristics such as age, religion, schooling, party membership, and parents' schooling; $Z_{m}$ denotes whether $m$ is rural and the average income and schooling at district/township level; and ParentMatched ${ }_{i m}$ is a dummy variable indicating whether $i$ 's parents were involved in the search for his wife. The instrument that captures the norm of parental matchmaking in market $m$ is denoted as

\footnotetext{
${ }^{10}$ The district level in urban areas is one level below the county-level city in China's administrative ladder.
} 
$\overline{\text { ParentMatched }}_{m}$.

While $\overline{\text { ParentMatched }}_{m}$ filters out individual-level unobservable attributes, it also introduces a general equilibrium problem, that is, the effect of $\overline{\text { ParentMatched }}_{m}$ on one individual may be offset by that on another individual in the same marriage market so that the effect of the norm may reflect spurious correlation due to the omission of other market-level variables. Take wife schooling as an example. Let us assume that every girl has completed her schooling before entering the marriage market and every girl is eventually married. If we compare two marriage markets with exactly the same distribution of girl schooling, then the average wife schooling must be equal regardless of which market uses more parental matchmaking. A shift in $\overline{\text { ParentMatched }}_{m}$ will only affect who matches with whom, not the market-wide average. In reality, the market with a higher $\overline{\text { ParentMatched }}_{m}$ may be associated with lower average wife schooling for other reasons, for example, such a market may also have an unobserved culture to discourage girl schooling. In this situation, using $\overline{\text { ParentMatched }}_{m}$ as an instrument may pick up this unobserved culture but does not support the argument that parents prefer a less educated daughter-in-law.

To address the potential general equilibrium problem, we need individual-level variations in the instrument. One solution is interacting the market-wide social norm $\left(\overline{\text { ParentMatched }}_{m}\right)$ with some individual-level variable, say husband schooling $\left(h_{m}\right)$. According to our model, although social norm does not affect the average wife schooling based on a predetermined wife schooling distribution, it does affect the assortative matching between husband schooling and wife schooling. Therefore, even if $\overline{\text { ParentMatched }}_{m}$ alone captures some unobserved cultural factor beyond our model, using $\overline{\text { ParentMatched }}_{m} \cdot h_{i m}$ as instruments for ParentMatched $_{i m} \cdot h_{i m}$ will shed light on the effect of parental matchmaking on the matching pattern of husband and wife schooling.

Again partly to address the general equilibrium problem, our second main instrument is a pure individual-level instrument based on the characteristics of the husband's first job. ${ }^{11}$ Since the vast majority of husbands should have obtained their first jobs before dating, the nature of the first job may affect the husband's own social circle and therefore his search cost before marriage, but it should not affect the couple's marriage outcomes directly at the time of survey after we control for the husband's current job status. ${ }^{12}$ Empirically, we define a dummy for whether an urban husband's first job was in a state-owned enterprise and another dummy for whether a rural husband's first job was in a township and village enterprise. Both dummies are referred to as $J o b_{0}$. In the empirical section, we provide a

\footnotetext{
${ }^{11}$ We thank one referee for inspiring us to look at the husband's first job as an individual-level instrument.

${ }^{12}$ We have tested this argument empirically. When we include both first job and current job in the OLS regressions, the coefficients on the first job variables are not statistically significant.
} 
number of tests for the validity and power of $J_{o b_{0}}$ and $\overline{\text { ParentMatched }}_{m}$ as instruments.

It is worth noting that the general equilibrium concern is more severe for wife schooling than for other marriage outcomes, as most girls have completed education before marriage, and hence the distribution of wife schooling is largely pre-determined. In contrast, joint couple income, wife's labor participation, wife submissiveness, fertility outcome, or even the husband's belief in old age support can be influenced by parental preference after marriage, and their average may therefore differ from one market to another even if all markets start with the same distribution of wife characteristics. In other words, social norm (as proxied by $\overline{\text { ParentMatched }}_{m}$ ) could have a causal effect on these other marriage outcomes according to our theoretical model, even if its identification relies on cross-market comparison.

\section{$3 \quad$ Data and Measurements}

\subsection{Data Source}

We use the Study of the Status of Contemporary Chinese Women (SSCCW), a data-set collected jointly by the Population Institute of Chinese Academy of Social Science and the Population Council of United Nations in 1991 (Institute of Population Studies, 1993). SSCCW collects information on personal traits, marriage characteristics, fertility, work, intra-family arrangements, and gender norms. The survey used stratified random sampling to select households from one municipality (Shanghai) and 6 provinces (Guangdong, Sichuan, Jilin, Shandong, Shanxi, and Ningxia) scattered across China in the southeast, south, southwest, northeast, east, middle and north, respectively. As migration across different provinces was not common in China by 1991, each province can be regarded as a separate marriage market. Another important dimension that cuts across areas is the urban-rural distinction. The rigid Hukou system effectively blocked people from migrating between cities and the countryside at the time of the survey. Furthermore, although our data consist of married couples only, we do not face much selection in divorce. The divorce rate around our sample period was only 0.71 per 1000 couples, far below the corresponding numbers in many countries in 1995, which are 4.44 in the U.S. and 1.59 in Japan (Zeng and Wu, 2000).

SSCCW interviewed husbands and wives separately. Here we focus on the male sample because a Chinese couple tends to live with the husband's parents by tradition (if they live with any parent at all), and the paternal parents therefore have stronger incentives to value a marriage candidate's ability in economic and home production. Our sample thus consists of husbands. Wife characteristics will be examined as dependent variables, as they are the result of the choice of the husband (and his parents if they were involved in the search 
process).

\subsection{Key Variables}

The question on matchmaking methods asked how an individual met his or her spouse initially. There are four original categories in the data: introduced by parents or relatives, by friends, by themselves, and by other means. We define a dummy of ParentMatched equal to one if the husband has been matched by the introduction of parents or relatives and 0 if otherwise. We cannot distinguish parents from relatives partly because the distinction is not available in the data, partly because relatives are an integrated part of the parents' social networks to facilitate the search process. A perhaps more debatable decision is that we do not differentiate couples initially introduced by friends from those who met by themselves. The reason is that these two groups are similar: in both cases, it is the young people themselves, not their parents, who conducted the search process and bore the search cost. And indeed, our empirical explorations suggest that these two groups are very similar.

The survey also asked whether the marriage decision was made by self or parents. Subjects were asked to choose from "self decision, parental consent", "self decision, parental disapproval", "self decision, parental consent on both sides", "self decision, parental disapproval on both sides", "parental decision, self indifferent", "parental decision, self consent" and "parental decision, self consent by force." Answer to this question differs greatly by whether ParentMatched is equal to one. For the sample of husbands, $33.8 \%$ of them had parental matchmaking. Among those parent-matched marriages, $26.6 \%$ were parental decision rather than self decision. In comparison, only $6.9 \%$ of self matched marriages were parental decision. But most parent-decided marriages have the answers of either "I consented" (78\%) or "I was indifferent to self decision or parent decision" (18.6\%). Only $3.4 \%$ of them fall in the category of "it was parental decision, and I was forced to agree." This is consistent with our model assumption that parents cannot force a marriage on an adult son in modern China. Rural parents play a more important role in their children's marriage life than urban parents, as reflected in our data: $48 \%$ of our rural couples were married via parental matchmaking, while this percentage is only $14.5 \%$ for urban couples. Moreover, $30.5 \%$ of parent-matched husbands had their marriage decided by their parents in rural areas, as compared to $13.8 \%$ in urban areas.

From a husband's perspective, marriage outcomes are represented by love, joint income, non-marketable household production, wife traits, the number and gender composition of children. Given the difficulty to quantify love, we follow Huang, Jin and Xu (2012) to proxy the emotional dimension of marriage by an indicator of harmony within a couple. 
The survey question most closely related to the emotional aspect of marriage asked: "How do you usually reconcile with your spouse when you have conflicts?" We define a harmony index as follows: it is equal to 2 if the couple reported no conflicts, 1 if conflicts are usually solved by mutual compromise, and 0 if conflicts are solved by either unilateral compromise or third-party mediation by family members, relatives or friends. Third-party involvement in conflict solution is a rare event in the data (only $3 \%$ reported so) so we do not distinguish it from unilateral compromise. The implication is that "no conflicts" is the best outcome, while "mutual compromise" comes next in the ranking, which is arguably less costly or more effective than unilateral compromise and third-party mediation. Mutual compromise is better than unilateral compromise also because constant reliance on unilateral compromise eventually leads to resentment and the loss of love. In our view, this harmony index captures the essential meaning of a couple's matching quality: couples with better matching quality are less likely to have conflicts and more capable of solving conflicts in an effective way. Though imperfect, the above-mentioned harmony index is a more appropriate measure of the emotional output of marriage in our context than others used in the literature. In modern western societies, for example, whether a marriage ends up in divorce is a natural measure of marital quality. The extremely low divorce rate in China by 1991, along with the fact that our data cover married couples only, however, renders this measure less useful.

Joint couple income is measured by the summation of the annual incomes of the husband and of the wife. This is a measure for the market component of marriage gains. Keep in mind that maximized couple income could be achieved either by both working for market incomes or by specialization, that is, one works for the market while the other specializes in household production.

Wife's labor participation status (at the time of survey) is defined separately for urban and rural areas. In urban areas, there is an explicit question on whether the wife has any job outside home. In rural areas, one question asked about a rural wife's main labor type: household chores, agriculture, household husbandry, household processing, household craft, individual peddler, township and village enterprises, and other. However, "household chores" can entail a large account of income, as high as 3,000 yuan per year at the $95 \%$ percentile and 11,700 yuan at the maximum. Thus we suspect some respondents have included some market-oriented activities in "household chores". To be safe, we classify whether a rural wife was working in the labor market based on whether her annual income is above 1,500 yuan. This definition is very much correlated with the reported labor type: for those who reported "household chores" as the main labor type, 35\% is labeled "work" by our 1500-yuan definition; in contrast, of those who reported anything other than "household chores" as the main labor type, $67 \%$ is labeled "work" by our definition. Later on we have also used above-1000 yuan 
as an alternative definition for rural wife's labor participation status and find robust results.

A significant share of residents, especially the rural ones, rely on adult children for old age support. On the question of "what do you expect to get from your son when you grow old?" $4.6 \%$ of urban husbands answered financial support, $43.5 \%$ answered home services, $38.2 \%$ answered emotional support, and $13.2 \%$ answered that they expected nothing. In comparison, $19.8 \%$ of rural husbands expected financial support from their sons, $67 \%$ expected home services, $9.1 \%$ expected emotional support, and only $3.8 \%$ reported that they expected nothing. Similar patterns occur on a parallel question of "what do you expect to get from your daughter when you are old?" but both urban and rural husbands expected more emotional support from their daughters (41.5\% in urban and $29.8 \%$ in rural), and less financial support $(2.4 \%$ urban, $11.5 \%$ rural $)$ than from sons. On home services, urban husbands expected about same home services from daughters (44\%) as from sons (43.5\%), while rural husbands expected less home services from daughters (51.4\%) than from sons $(67 \%)$.

Consistent with our discussion that wives are key for providing various home services including services related to old age support, we find that wives are likely to contribute more to old age support than husbands inside the household. The SSCC survey asked urban husbands and wives separately on "who is the main provider" of certain types of house work, including "home service to the elderly". Conditional on existing need of home service to the elderly, $40 \%$ of husbands and $57 \%$ of wives said they were the main service provider in the house. Husbands seem to exaggerate their role as the main contributor: while only $39 \%$ of husbands admitted that their wives being the main provider of old age support, $57 \%$ of wives claiming themselves being the main provider. Similarly, $23 \%$ of wives credited their husbands as the main contributor of old age support in the house, while $40 \%$ of husbands credited as such themselves. Unfortunately, this question was not asked in the rural sample, but rural couples were more likely to live with the husband's parents at the time of marriage (59\% rural, 31\% urban, according to husband's answer), and it is quite rare to live with the wife's parents in both rural and urban areas (5\% rural, 6\% urban, according to husband's answer). At the time of the survey, fewer rural couples were still living with the husband's parents (29\% rural and $39.9 \%$ urban), but this is partly because more rural parents have passed away, and rural parents have more children to live with so that the probability of living with a particular child would be lower.

To recap, the survey data confirm that parents, especially rural parents, rely on their adult children for old age support, and old age support is typically provided by son and daughter-in-law. Within the couple, the wife is more likely to provide home services to the elderly if such need arises. All these suggest that parents have strong incentives to participate 
in the choice of their daughter-in-law, especially in rural areas.

Because old age support in the household is usually provided by the wife, its effective delivery requires values and beliefs conforming to a traditional society. Indeed, for thousands of years in Chinese history, a top value for children is filial piety (Cheung, 1972), which emphasizes being obedient and submissive to parents. Interestingly, the second Chinese character in the term filial piety, xiao shun, literally means being submissive and following orders of parents. This is especially important for picking a wife for the son: the son was already trained to be obedient to parents within the household for all the growing-up years, but the wife will join the family as an adult and it may be difficult to train her to be submissive after marriage. Thus, matchmaking parents would prefer to select a young woman who has already submitted to those submissive values and is more malleable to the happiness of the husband's parents.

To measure the submissiveness of the wife, we rely on three specific measures and one aggregate measure. First, Wife Career Unimportant is a dummy variable indicating an answer in agreement to the following statement: a wife's career achievement should not exceed that of her husband. This indicates conformity to the traditional value of superiority of man over woman (Cheung, 1972), and makes husbands' wishes easier to carry through in the family. Second, No Good Male Friend is a dummy variable indicating the belief that a married woman should not have a good male friend. Again, this is a preventive belief that helps to maintain the value of parental investment in picking a submissive and cooperative wife for their son. With such a belief, there is a much lower chance of marriage disruption, and parental investment in picking the right wife would have a longer horizon to bear fruit. This is very similar to what Cheung (1972) interpreted about the Chinese marriage practice of "blind marriage" (i.e., groom and bride were supposed to meet each other for the first time upon the completion of the procedure on the wedding day): it disallows a young man's love for beauty to stand in the way of maximizing family wealth via arranged marriages. Third, Cannot Reject Sex is a dummy variable that is based on the following question: "do you think a wife can reject her husband's request for sex? 1. yes, 2. no, 3. yes but hard to get it accomplished." If the answers are 2 and 3, then the dummy Cannot Reject Sex takes the value of one. Finally, the three measures are summed into an aggregate index, Wife Submissiveness. Clearly, a higher value of Wife Submissiveness implies a wife who is more submissive, easier to govern, and more conducive to parents' old age support. As a comparison, we also measure wife traits by wife schooling. Since highly educated women often have their own ideas and face more job and social opportunities outside home, parents may face a tradeoff between having a highly educated daughter-in-law and having a submissive one. 
We also measure the husband's belief in providing old age support. Having such a belief is a key part of BMS (2015): to ensure old age support, parents invest resources in manipulating children's preferences so that they are more altruistic toward the parents. Because we argue that parental matchmaking leads to a better fulfillment of parents' agenda which includes old age support, we follow BMS (2015) to examine whether parental matchmaking is systematically associated with the son having stronger preferences for providing old age support. One survey question asked: "in your view, what is the best way to allocate household assets? 1. to distribute evenly among sons and daughters, 2. mainly to sons, 3. mainly to daughters, 4 . to the sons or daughters that provide old age support." When the answer is 4, the newly created dummy variable, Providing Old Age Support, is set equal to 1.

One may argue that Providing Old Age Support can be interpreted as a measure of incentives rather than preferences for providing old age support. We however interpret it mainly as a belief: the wording is not about whether the husband in our survey had received an ex-ante offer of inheritance conditional on providing old age support. Such contracts are uncommon and unenforceable in China. Rather, the question is among a long list of belief questions, and it is worded as whether the surveyed husband would reward the care-giving children for providing old age support to him. When the husband believes that providers of old age support deserve more household assets, two scenarios are likely: either the responding husband inherently believes in the moral value of adult children providing old age support, or his parents (or the local community) have instilled this value in him. Either way, those believing in Providing Old Age Support tend to have a stronger belief in the duty of adult children in providing old age support to their parents.

We measure the couple's fertility outcome by their number of children at time of survey, whether the number of children is above three, and whether the couple have at least one son. We choose three as the cutoff because rural areas do not enforce the one-child policy strictly if the first child is a girl, hence it is common to have two children in a rural household. Having three or more requires more determination and more financial resources to pay a fine for violating the one-child policy.

As stated in Section 2, social norm $\overline{\text { ParentMatched }}_{m}$ is measured by the proportion of parent-matched couples in a marriage market defined by province, urban/rural, and age cohort. Age cohorts are defined as those at the same age or up to three years older. The other instrument, $\mathrm{J}_{o b_{0}}$, includes two dummies: one for whether an urban husband's first job was in a state-owned enterprise and the other for whether a rural husband's first job was in a township and village enterprise. We control for husband's schooling, age, mother schooling, father schooling, membership of Communist Party and current job status. The current job status includes ten dummies: for an urban husband, we code whether his current job is a 
state-owned enterprise, a collective firm, a privately owned firm, a foreign firm or a firm of other ownership types; for a rural husband, we code whether his current job is in household production, farming, household non-agricultural activities, a township and village enterprise, or other activities. At the district/township level, we control for log income per capita and average schooling. Whether the area is urban or rural is absorbed by the husband's current job status.

\subsection{Sample and Summary Statistics}

As detailed in Section 2, parental matchmaking is subject to individual-level selection, and our instruments include the local norm of parental matchmaking. As a result, we need a sample sufficiently large to compute the norm in each province-urban-age cell where age refers to the same age as or up to three years older than the survey respondent. We thus delete any province-urban-age cells that contain fewer than 35 observations. The number of 35 is somewhat arbitrary, but it ensures a reasonable number of observations to compute the mean (excluding oneself), while at the same time not losing too many observations of the sample. This restriction leads to a sample with males no older than early 50 s at the time of survey (1990). Dropping old males has an added benefit: the individuals who remain in our sample do need to consider old age support for their parents, which suits the purpose of this paper. In total, we have 6,334 husbands in the analysis sample, $57.6 \%$ of whom lived in rural areas at the time of survey.

Table 1 presents the summary statistics for the pooled sample first, and then parentmatched and self-matched samples separately. Column 4 presents the difference between the parent-matched and self-matched couples, along with the standard deviation and t-statistics of the mean comparison. Overall, 33.8\% of couples were formed via parental matchmaking, but rural couples relied on parents for matching much more frequently (48\% vs. 14.5\%). Relative to self-matched couples, the parent-matched are less harmonious, more likely to have conflicts, and have lower combined income. Husbands in parent-matched marriages have significantly lower schooling (by 1.6 years), significantly less educated parents (by 1-2 years), and are less likely to be a Communist Party member, which is associated with higher earning power (Li et al., 2007). While these attributes are consistent with the selection story - less desirable men are more likely to get help from parents in spouse searching - parent-matched husbands actually get married 1.6 years younger than the self-matched. One possible explanation is that they are subject to more traditional family values and face more pressure to marry early. This is confirmed by different strengths of parental matching norm (0.45 for parent-matched couples and 0.3 for self-matched couples). Consistent with our prediction, parent-matched husbands also tend to have more children (1.895 vs. 1.518) 
and a higher likelihood to have at least one son (0.753 vs. 0.637). Urban husbands were less likely to start the first job in a state-owned enterprise if they were matched by their parents, but there is no significant difference in whether a rural husband started his first job in a township or village enterprise. Neither is there significant difference in the husband's belief on providing old age support between parent- and self-matches.

Wives in parent-matched marriages have 2.4 fewer years of education, are less likely to work outside home, and earn less annual income. Parent-matched wives are more likely to be submissive than self-matched wives by $1 / 3$ standard deviation. These significant differences between self- and parent-matched couples suggest serious selection of parental matchmaking by individual characteristics. That being said, parental matchmaking is associated with lower values in indicators of local development as well. Parent-matched marriages are more likely to appear in places where the norm of parental matchmaking is stronger, the average income is lower, and the average schooling is lower. Given the rigid hukou system in China and the lack of migration in 1990, these geographic differences are likely beyond the control of any individual in our sample.

Table 2 examines the assortative matching property between husband schooling and wife schooling. If parental matchmaking is mainly used as the last resort when an unattractive man could not find a wife by himself, parental matchmaking should be negatively correlated with husband schooling at the individual level (as we have seen in Table 1), but the marketwide proportion of parental matchmaking should not correlate with the assortative matching between husband and wife schooling. On the other hand, if parents engage in matchmaking with an eye on the traits of the daughter-in-law that may help them obtain more parental goods, they may intentionally reinforce or weaken the assortative matching in schooling. Defining each marriage market by province-urban-age, Table 2 shows that a husband and a wife are much less assortatively matched if the market has a stronger norm for parental matchmaking. In other words, parents of a highly educated man may prefer a daughter-inlaw of lower education than what will arise in a self-matched market. This result is significant and robust even after we control for the average schooling of the province-urban-age cell, which is likely to indicate the educational and economic development of that market.

Using the husband sample, Table 3 shows a linear-probability estimation on the determinants of parental matchmaking. ${ }^{13}$ Starting from a benchmark regression in Column (1), we progressively add the instruments $\left(\overline{\text { ParentMatched }}_{m}, J_{o b_{0}}\right.$, and $\overline{\text { ParentMatched }}_{m}$. Schooling) in Columns (2), (3) and (4). As expected, local social norm in parental matchmaking is strongly and positively correlated with individual choices of parental matchmaking even after we control for many observable husband and local attributes. The type of first

\footnotetext{
${ }^{13}$ Similar results are found when using probit.
} 
job seems to matter too, where a rural man who started his first job in a town and village enterprise is less likely to use parental matchmaking. The schooling variables, however, do not exhibit any significant impact on whether a son uses parental help in matching, which is still true when alternative schooling categories are used. An explanation for this lack of effect is that the human capital variable in our model is much more general than formal schooling; it also includes a person's character and charisma, which are often unobservable but influential in matchmaking. This is why we need to use instruments to control for the selection effect.

\section{Empirical Results}

\subsection{Love and Joint Income}

We first show how parental matchmaking relates to marital harmony and joint couple income. To isolate the effects of parental matchmaking, we include a long list of control variables: the husband's (1) own age (in log) and schooling; ${ }^{14}$ (2) parents' schooling; (3) political affiliation with the Communist Party; (4) religion dummies (Muslim, Christian, Buddhist) and ethnicity dummies (Hui, Korean, Manchu, or other minorities); (5) current job type (10 dummies); and (6) local development as measured by the average income and schooling in the district or township where the couple live. ${ }^{15}$ Rural and urban regions differ greatly in marriage markets, but the husband's current job type already accounts for the rural-urban difference hence we do not report a separate coefficient on the rural dummy.

The key-right-hand side variable is parental matchmaking. As discussed in Section 2, a less competent son with more competent parents is more likely to rely on parental search. This is why we control for both child and parent characteristics in the regression. Nevertheless, selection based on unobservable individual characteristics is still likely. To deal with such individual-level selections, Table 4A first reports the OLS result and then progressively use $\overline{\text { ParentMatched }}_{m}$, Job 0 , and both as instruments for the matchmaking choice. The first four columns focus on harmony, while the last four columns focus on log joint couple income. All standard errors are White-corrected and clustered at the district/township level since we have local income and schooling controls at this level. The first-stage Kleibergen-Paap Wald Rank (KPWR) F statistics and the AR weak-instrument robust test (Finlay and Magnusson, 2009) are reported at the bottom of each IV column. Whenever we use more than one

\footnotetext{
${ }^{14}$ We got similar results when including age and age squared instead.

${ }^{15}$ The average income and schooling are computed based on sample information. We exclude the self in computing the local average to avoid artificial correlation of these variables and the outcomes of an individual. We have also tried including other variables such as the firm ownership dummies of the husband's first job. Their inclusion did not affect any of our key results.
} 
instruments, we report the p-value for Hansen's J test for over-identification.

Parental matchmaking is robustly correlated with lower marital harmony. The coefficient of ParentMatched is negative and significant in the OLS regression. The instrumental variable estimate is again negative, more pronounced in magnitude, and statistically significant in all three columns of the IV results. The KPWR F-statistics and the AR weak instrument test suggest that both $\overline{\text { ParentMatched }}_{m}$ and $J_{o b} b_{0}$ have enough power to function as instruments. The p-value of Hansen's J statistics also suggests a pass of the over-identification test. According to the IV estimate in Column 4, increasing ParentMatched by one standard deviation (0.47) would lead to a drop in Harmony by 2.54 standard deviation. The results are consistent with the agency model where parents' emphasis on sharable marriage production leads to a sacrifice in non-sharable outcomes such as marital harmony.

On joint couple income, the IV results suggest that ParentMatched has a negative effect over the whole sample and the sign of this result is robust to different instruments. At the first glance, this is at odds with our previous work on the urban sample of the same survey (Huang, Jin and $\mathrm{Xu}, 2012$ ). Further study shows that this difference is driven by the urban-rural distinction. In Table 4B, we repeat the OLS and IV estimation (using both $\overline{\text { ParentMatched }}_{m}$ and $J_{o b_{0}}$ as instruments) but include an interaction of the rural dummy and ParentMatched. While parent-matched couples suffer from lower harmony in both rural and urban areas, ParentMatched has a positive effect on joint couple income in urban areas but a negative effect in rural areas. The IV results suggest that an increase in ParentMatched by one standard deviation for urban areas would lead to an increase in couple income by 0.2 standard deviations, consistent with Huang, Jin and Xu (2012). For rural areas, the corresponding effect is a drop in couple income by 0.3 standard deviations.

The rural-urban distinction reflects different patterns of parental goods and different institutional constraints. First, in urban areas, market opportunities are more abundant for both labor and services such as meals, laundry and care-giving, yet the enforcement of one-child policy is more stringent. Both factors contribute to urban couples relying more on monetary income (relative to household production) to deliver parental goods. As a consequence, parents in their self-interest would want to ensure that the marriage yields relatively high income. In contrast, in rural areas, there are fewer opportunities to make money and buy services (at least during our sample period of early 1990s); but there are more opportunities to evade the one-child policy. As a result, rural parents rely more on married children to provide parental goods directly. We thus witness a substitution of market production by household production in rural areas, which explains the negative effect of parental matchmaking on (market) couple income in rural areas. ${ }^{16}$

\footnotetext{
${ }^{16}$ The rural-urban separation also helps to explain why the Hansen's J statistics do not pass the over-
} 


\subsection{Wife Schooling, Labor Market Participation, Income and Submissiveness}

To ensure the provision of parental goods, parents may prefer certain traits in the daughterin-law. Such traits may be proxied directly by wife schooling, or reflected indirectly by wife-related marriage outcomes such as wife's labor market participation, income and submissiveness. Since some wife traits may conflict with each other-for example, a highlyeducated wife may bring more labor market income to the household but do fewer household chores and tend to be less submissive in the household; what traits are more preferable by parents via parental matchmaking remains an open empirical question.

Table 5 reports the OLS and IV results on wife schooling. Because wife schooling is pre-determined before marriage, as discussed earlier, there is a potential general equilibrium problem if we only use market-wide social norm $\left(\overline{\text { ParentMatched }}_{m}\right)$ as the instrument. We address it by also using $J o b_{0}$ and $\overline{\text { ParentMatched }}_{m} \cdot$ Schooling $_{i m}$ as individual-level instruments for ParentMatched ${ }_{i m}$ and ParentMatched $d_{i m} \cdot$ Schooling $_{i m}$. While the IV coefficient on ParentMatched ${ }_{i m}$ alone may confound the true effect with the market-wide unobserved traditional value on female education, the negative IV coefficient of ParentMatched $_{i m}$.

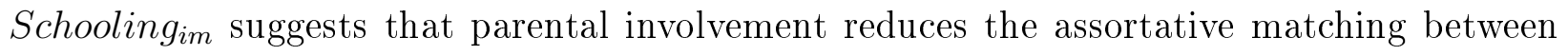
husband schooling and wife schooling, which is consistent with the market-wide evidence presented in Table 2. The optimal individual selection model cannot explain why a man facing the same distribution of wife schooling tends to prefer a less-educated wife when parental matchmaking is more prevalent in the marriage market, but the influence of parental preference can do so.

Table 6 looks at a wife's annual income and labor participation directly. As described in Section 3, a rural wife's labor participation is defined by whether her reported annual income is above 1,500 yuan; this threshold is lowered to 1,000 yuan in the alternative measure. An urban wife's labor participation is defined by whether she has a job outside home. Overall, parent-matched wives earn significantly less and are less likely to participate in the labor market. This finding is significant in both OLS and IV specifications. One explanation is that wives in parent-matched marriages are less able to earn income from the labor market, as suggested by their lower schooling (Table 5). Another possibility is that they tend to specialize more in household production, which is consistent with parents' interest in household services.

To check whether parental matchmaking favors a submissive wife, a key condition for delivering parental goods in traditional societies, Table 7 reports regression results first on

identification test in the full sample for joint couple income (Table 4A). Once we account for the rural-urban difference, the Hansen's J statistics are no longer significant at the $90 \%$ confidence level for joint couple income (Table 4B). 
the aggregate measure of Wife Submissiveness, and then on the three specific measures separately. The correlation of ParentMatched with the overall Wife Submissiveness is positive and marginally significant. After instrumenting ParentMatched, the effect becomes significant at conventional levels and larger in magnitude.

The rest of Table 7 relates ParentMatched to Woman Career Not Important, No Good Male Friend, and Cannot Reject Sex. Results suggest that parent-matched wives tend to emphasize less on women's careers. Further analysis suggests that this is mostly driven by rural wives, while urban wives in parent-matched marriages do not differ from other marriages in terms of downgrading the importance of women's careers. ${ }^{17}$ Again, this is consistent with endogenous preference (Becker, 1996): in urban areas where market opportunities are greater for women and many household services can be outsourced to the market, less career discouragement is imposed on women; in rural areas where market opportunities are less for women and parental goods rely on within-household services, parents discourage women's market value more. Turning to No Good Male Friend, parent-matched wives are more likely to believe that a married woman should not have good male friends. This attitude/preference is consistent with more marriage stability and more attention to household production. After all, outside friendship with the opposite sex could lead to more time spent outside the household or emotional distraction, both of which may destabilize marriage and reduce the returns of investments that parents have already made in finding the suitable mate for their son. In both OLS and IV regressions, we do not find a significant correlation between ParentMatched and whether the wife believes that she should not reject sex requests by her husband. Nevertheless, we do observe a significant difference in fertility between parentand self-matched marriages, which we will describe below.

\subsection{Fertility and Belief in Old Age Support}

Parents may benefit directly from a greater number of grandchildren by enjoying the pleasure of companionship, help, and simply the altruistic impulse of seeing them growing ("my genes are alive and well in them"). In modern society where adult children are often busy working, grandchildren become regular companions for grandparents at home, and make them feel more valuable to family. Admittedly, high fertility may dilute resources available to everyone else in the family, but the cost of bearing and raising more kids may fall disproportionally on parents than on grandparents: for example, having more children means more effort at childcare and less market participation at least by mothers, while the benefits of more children are enjoyed more directly by grandparents. Indirectly, altruistic parents may view

\footnotetext{
${ }^{17}$ Results are available upon request.
} 
more grandchildren as a warranty for their son's old age support, and thus prefer the couple to have more children.

Table 8 reports three panels of results on the effects of parental matchmaking on fertility. Given the imperfect enforcement of the one-child policy in rural areas, it is common to have two children, so the margin for parents to push is on the third child. ${ }^{18}$ Traditional family value also suggests that parents may prefer grandsons to granddaughters (i.e., son preference), especially if they can instill this preference through selecting a more obedient daughter-in-law before marriage and push for having a boy after marriage. Consistent with our expectation, both the OLS and IV results suggest that parent-matched couples have more children and are more likely to have at least one boy.

BMS (2015) suggests that parents in need of old age support have incentives to induce more altruistic preference from their sons, in order to ensure smooth and committed delivery of old age support. To check this argument, we examine how husband belief in old age support differs across parent- and self-matched marriages. In the OLS results of Table 9, ParentMatched is positively and significantly correlated with Providing Old Age Support. When we use the instrument, the coefficient remains significant and of a large magnitude. According to the IV results, a one-standard-deviation increase in ParentMatched (0.47) is associated with a higher probability of parent-matched husbands to believe in Providing Old Age Support by 0.8 standard deviation. This evidence is consistent with BMS (2015).

\section{Conclusion}

While many economic studies have examined various aspects of marriages, little attention has been paid to the role that parents play in their children's marriage formation, to how various matchmaking means affect the selection of spouse and marriage outcomes, and to how institutional differences such as the provision of old age support shape the effect of matchmaking means. In this paper, we use unique data on Chinese households in the early 1990s to examine what types of people use parental matchmaking (versus relying on self matches), and how parental matchmaking affects marriage harmony, income, fertility, the belief in providing old age support, and wife traits that are conducive to the delivery of parental goods.

In a simple theoretical framework, we show that parental matchmaking may distort the son's optimal spouse selection because parents emphasize a potential wife's ability and temperament for providing sharable household goods, and downplay the love or emotional chemistry within the couple. Put differently, relative to the son, parents are more willing to

\footnotetext{
${ }^{18}$ Three or more children is much less likely in urban (6.3\%) than in rural areas (23.5\%).
} 
substitute love within the couple for sharable parental goods (including old age support).

We find supporting evidence for the model: parental matchmaking is associated with less marital harmony within the couple, more submissive wives, less labor market participation of wives, lower wife income, a greater number of children, a higher likelihood of having any boy, and the husband's stronger belief in providing old age support. These results render support to the view of BMS (2015) that parents would meddle with children's preferences to ensure their commitment to providing parental goods such as old age support.

We also find suggestive evidence that urban and rural areas use different supporting mechanisms for parental goods. In urban areas, with more labor market opportunities and more stringent enforcement of the one-child policy, parents rely more on the monetary income channel to ensure old age support, and as a result, parental matchmaking is associated with higher joint couple income (Huang et al., 2012). In contrast, in rural areas, labor market opportunities are fewer and it is easier to evade the one-child policy. As a result, parents rely more on household production, and joint income tends to be lower for parent matched couples than for self-matched couples in rural areas. The rural-urban difference is consistent with an insight from Cheung (1972): institutions often evolve to serve the prevalent needs of economic players. Here, parental matchmaking is conducive to the delivery of parental goods: when market is less effective, parental matchmaking is more likely to be adopted to ensure that parental goods are adequately provided by married children.

Overall, our analysis suggests that parental matchmaking introduces an interesting tradeoff. On the one hand, it entails agency costs in terms of less love within the couple. On the other hand, it helps to ensure parental goods for the matchmaking parents, and a more harmonious inter-generational relationship. Since our sample period, China has evolved towards more state-provided pension and health insurance for rural households and the urban poor. As more and more old age support is provided outside household, and more labor market opportunities arise even for rural people through means such as migration, traditional values such as filial piety and submissiveness of children may become less important for parents and increasingly unproductive for the society as a whole (e.g, it may discourage risk-taking and innovation among the young), not to mention that it is also more difficult to enforce such values when inter-generational cohabitation becomes rarer. If our theory is right, we expect parental matchmaking to play different roles in this transition. After all, with more old age support from the society and more market offering for household services, parents have less need to manipulate children's preferences or to select submissive but less capable (in market production) daughters-in-law. This topic warrants future research. 


\section{References}

[1] Anderson, Siwan, 2003. Why dowry payments declined with modernization in Europe but are rising in India. Journal of Political Economy 111(2), 269-310.

[2] Anderson, Siwan, 2007. The economics of dowry and bride price. Journal of Economic Perspectives 21(4), 151-174.

[3] Angrist, Joshua, 2002. How do sex ratios affect marriage and labor markets? Evidence from America's second generation. Quarterly Journal of Economics 117(3), 997-1038.

[4] Baker, Hugh, 1979. Chinese Family and Kinship. Columbia University Press, New York, NY.

[5] Becker, Gary, 1973. A theory of marriage: Part I. Journal of Political Economy 81(4), $813-46$.

[6] Becker, Gary, 1974. A theory of marriage: Part II. Journal of Political Economy 82(2), S11-S26.

[7] Becker, Gary, 1981. A Treatise on the Family. Harvard University Press, Cambridge, MA.

[8] Becker, Gary, 1996. Accounting for Taste. Harvard University Press, Cambridge, MA..

[9] Becker, Gary, Kevin M. Murphy, Jorg Spenkuch, 2015. The manipulation of children's preferences, old age support, and investment in children's human capital. Journal of Labor Economics 34(S2), S3-S30.

[10] Blood, Robert, 1967. Love Match and Arranged Marriage. Free Press, New York, NY.

[11] Chao, Paul, 1983. Chinese Kinship. Kegan Paul International, London, Boston and Melbourne.

[12] Chiappori, Pierre-Andre, Bernard Fortin, and Guy Lacroix, 2002. Marriage market, divorce legislation and household labor supply. Journal of Political Economy 110(1), $37-72$.

[13] Cheung, Steven, 1972. The enforcement of property rights in children, and the marriage contract. Economic Journal 82, 641-657.

[14] Cohen, Myron, 1992. Family management and family division in contemporary rural China. China Quarterly 130, 357-377. 
[15] Davidson, Audrey, and Robert Ekelund, 1997. The Medieval church and rents from marriage market regulations. Journal of Economic Behavior and Organization 32, 215245.

[16] Edlund, Lena, and Nippe Lagerlof, 2002. Individual versus parental consent in marriage: Implications for intra-household resource allocation and growth. The American Economic Review 96(2), 304-307.

[17] Fernandez, Raquel, Guner Nezih, and Knowles John, 2005. Love and money: A theoretical and empirical analysis of household sorting and inequality. Quarterly Journal of Economics 120(1), 273-344.

[18] Finlay, Keith, and Leandro M. Magnusson, 2009. Implementing weak-instrument robust tests for a general class of instrumental-variable models. Stata Journal 9(3), 398-421.

[19] Foster, Andrew, and Mark Rosenzweig, 2000. Missing women, the marriage market and economic growth. Working paper, University of Pennsylvania.

[20] Heckman, James, 2008. The role of income and family influence on child outcomes. Annals of the New York Academy of Sciences 1136, 307-323.

[21] Hoff, Andreas, 2007. Patterns of intergenerational support in grandparent-grandchild and parent-child relationship in Germany. Ageing and Society 27, 643-665.

[22] Huang, Chong, Li Hongbin, Liu Pak Wai and Zhang Junsen, 2009. Why does spousal education matter for earnings? Assortative mating and cross-productivity. Journal of Labor Economics 27(4), 633-652.

[23] Huang, Fali, Ginger Zhe Jin, and Lixin Colin Xu, 2012. Love and money by parental matchmaking: Evidence from urban couples in China. American Economic Review Papers and Proceedings 102, 555-560.

[24] Ikkink, Karen Klein, Theo van Tilburg, and Kees C. P. M. Knipscheer, 1999. Perceived instrumental support exchanges in relationships between elderly parents and their adult children: Normative and structural explanations. Journal of Marriage and Family 61, 831-844.

[25] Institute of Population Studies, CASS, 1991. Sampling Survey Data of Women's Status in Contemporary China. International Academic Publishers, Beijing. 
[26] Johnson, David, Lynn White, John Edwards and Alan Booth, 1986. Dimensions of marital quality: Toward methodological and conceptual refinement. Journal of Family Issues 71(3), 31-50.

[27] Li, H.B., P.W. Liu, J.S. Zhang, and N. Ma, 2007. Economic returns to communist party membership: Evidence from urban Chinese twins. Economic Journal 117, 1504-1520.

[28] North, Douglas, 1990. Institutions, Institutional Change and Economic Performance. Cambridge University Press.

[29] Suen, Wing, William Chan and Junsen Zhang, 2003. Marital transfer and intrahousehold allocation: A Nash-Bargaining analysis. Journal of Economic Behavior Organization 52, 133-146.

[30] Weiss, Yoram, 1997. The Formation and Dissolution of Families: Why Marry? Who Marries Whom? And What Happens Upon Divorce? In: M.R. Rosenzweig, O. Stark (Eds.), Handbook of Population and Family Economics, Elsevier Science.

[31] Weiss, Yoram, and Robert Willis, 1997. Match quality, new information and marital dissolution. Journal of Labor Economics 15(1), S293-329.

[32] Xiaohe Xu, 1996. Measuring the concept of marital quality as social indicators in urban China. Social Indicators Research 37(2), 189-206.

[33] Xu, Xiaohe and Martin Whyte, 1990. Love matches and arranged marriages: A Chinese replication. Journal of Marriage and the Family 52(3), 709-722.

[34] Zeng, Yi and Deqing Wu, 2000. Regional analysis of divorce in China since 1980. Demography $37(2), 215-219$.

[35] Zhang, Junsen and William Chan, 1999. Dowry and wife's welfare: A theoretical and empirical analysis. Journal of Political Economy 107(4), 786-808.

[36] Zimmer, Zachary and Julia Kwong, 2003. Family size and support of older adults in urban and rural China: Current effects and future Implications. Demography 40(1), $23-44$. 


\section{Appendix A: Proof of Propositions}

The optimal values of $\alpha^{*}$ and $h_{f}^{*}$ are jointly determined by (1) and (2). Note that $\alpha^{*}$ can be solved from condition (1) as a function of $h_{f}^{*}$, which can then be plugged in (2) to solve $h_{f}^{*}$. The optimal values of $\alpha^{* *}$ and $h_{f}^{* *}$ are jointly determined by (3) and (4), based on which we get $\partial \alpha^{* *} / \partial h_{p}>0$ and $\partial h_{f}^{* *} / \partial h_{p}>0$ by Cramer's rule:

$$
\begin{aligned}
\frac{\partial \alpha^{* *}}{\partial h_{p}} & =\left|\begin{array}{cc}
\eta_{p}^{(-)} & (+) \\
\eta_{p} s_{23} & {\left[\gamma+\delta\left(\beta+\alpha_{1}^{* *}\right)\right] f_{11}-\eta_{p} s_{22}} \\
(-) & (-)
\end{array}\right| /|H|>0, \\
\frac{\partial h_{f}^{* *}}{\partial h_{p}} & =\left|\begin{array}{cc}
(-) & (-) \\
-\eta_{p} s_{11} & \eta_{p} s_{13} \\
\delta f_{1}-\eta_{p} s_{12} & \eta_{p} s_{23} \\
(+) & (-)
\end{array}\right| /|H|>0,
\end{aligned}
$$

where $|H|$ is the determinant of Hessian matrix

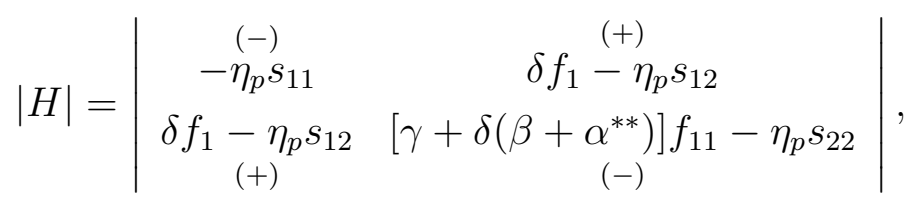

and $|H|>0$ is assumed for the existence of optimal solutions. We can also get $\partial \alpha^{* *} / \partial \gamma>0$ and $\partial h_{f}^{* *} / \partial \gamma$ in a similar way. We assume $\delta f_{1}-\eta_{p} s_{12} \geq 0$, which essentially means that $\partial^{2} \widetilde{U} / \partial \alpha \partial h_{f} \geq 0$; and then based on (3) we have

$$
\frac{\partial \alpha^{* *}}{\partial h_{f}}=\frac{\delta f_{1}\left(h_{f}^{*}, h_{m}\right)-\eta_{p} s_{12}\left(\alpha^{*}, h_{f}^{*}, h_{m}\right)}{s_{11}}>0 .
$$

Comparing conditions (1) and (3), we can see that $\alpha^{*}\left(h_{f}\right)>\alpha^{* *}\left(h_{f}\right)$ must hold, conditional on the same level of $h_{f}$; the reason is that the first terms in both conditions are independent of $\alpha$ while the second terms are strictly increasing in it, which combined with the assumption $\eta_{p} s_{1} \geq \delta \eta_{m} c_{1}$ will lead to $\alpha^{*}\left(h_{f}\right)>\alpha^{* *}\left(h_{f}\right)$. Given the same $\alpha$, we may have $h_{f}^{*}>h_{f}^{* *}$ if $\gamma<(1-\delta)(\beta+\alpha)$ and/or $\eta_{m} c_{2} \leq \eta_{p} s_{2}$, in other words, if parents do not benefit too much from the daughter-in-law's human capital $h_{f}$ or if their marginal searching cost with respect to $h_{f}$ is not lower than the son's. The opposite result $h_{f}^{*} \leq h_{f}^{* *}$ is otherwise possible.

Since the searching cost is always positive,

$$
\left(\beta+\alpha^{*}\right) f\left(h_{f}^{*}, h_{m}\right)>\left(\beta+\alpha^{* *}\right) f\left(h_{f}^{* *}, h_{m}\right)
$$


must hold, which then implies $\alpha^{*}>\alpha^{* *}$ and $\alpha^{*} f\left(h_{f}^{*}, h_{m}\right)>\alpha^{* *} f\left(h_{f}^{* *}, h_{m}\right)$; the reason is as follows. (i) If $h_{f}^{*}>h_{f}^{* *}$, then $\alpha^{*}\left(h_{f}^{*}\right)>\alpha^{* *}\left(h_{f}^{*}\right)>\alpha^{* *}\left(h_{f}^{* *}\right)$ holds, and it implies $\alpha^{*}>\alpha^{* *}$, where the first inequality follows $\alpha^{*}\left(h_{f}\right)>\alpha^{* *}\left(h_{f}\right)$ and the second follows $\partial \alpha^{* *}\left(h_{f}\right) / \partial h_{f}>0$. And $\alpha^{*} f\left(h_{f}^{*}, h_{m}\right)>\alpha^{* *} f\left(h_{f}^{* *}, h_{m}\right)$ follows directly from $h_{f}^{*}>h_{f}^{* *}$ and $\alpha^{*}>\alpha^{* *}$. (ii) If $h_{f}^{*} \leq h_{f}^{* *}$, then we have

$$
\left(\beta+\alpha^{*}\right) f\left(h_{f}^{* *}, h_{m}\right) \geq\left(\beta+\alpha^{*}\right) f\left(h_{f}^{*}, h_{m}\right)>\left(\beta+\alpha^{* *}\right) f\left(h_{f}^{* *}, h_{m}\right)
$$

where the first and third terms imply $\alpha^{*}>\alpha^{* *}$; the first inequality holds because $h_{f}^{*} \leq h_{f}^{* *}$, while the second inequality is based on (6). And following similar arguments we can derive $\alpha^{*} f\left(h_{f}^{*}, h_{m}\right)>\alpha^{* *} f\left(h_{f}^{* *}, h_{m}\right)$ by comparing the first and third terms in

$$
\beta f\left(h_{f}^{* *}, h_{m}\right)+\alpha^{*} f\left(h_{f}^{*}, h_{m}\right) \geq\left(\beta+\alpha^{*}\right) f\left(h_{f}^{*}, h_{m}\right)>\left(\beta+\alpha^{* *}\right) f\left(h_{f}^{* *}, h_{m}\right) .
$$

Based on (5), the utility difference between self and parents' searching is

$$
\pi \equiv U^{*}-U^{* *}=\left(\beta+\alpha^{*}\right) f\left(h_{f}^{*}, h_{m}\right)-\eta_{m} c\left(\alpha^{*}, h_{f}^{*}, h_{m}\right)-\left(\beta+\alpha^{* *}\right) f\left(h_{f}^{* *}, h_{m}\right),
$$

which is strictly decreasing in $h_{p}$ because

$$
\partial \pi / \partial h_{p}=-f\left(h_{f}^{* *}, h_{m}\right) \partial \alpha^{* *} / \partial h_{p}-\left(\beta+\alpha^{* *}\right) f_{1}\left(h_{f}^{* *}, h_{m}\right) \partial h_{f}^{* *} / \partial h_{p}<0 .
$$

We get $\partial \pi / \partial h_{m}>0$ for the following reason. Note that

$$
\partial \pi / \partial h_{m}=\frac{\partial U^{*}}{\partial h_{m}}-\partial\left(\beta+\alpha^{* *}\right) f\left(h_{f}^{* *}, h_{m}\right) / \partial h_{m}
$$

where

$$
\begin{aligned}
\frac{\partial U^{*}}{\partial h_{m}} & =\frac{\partial\left(\beta+\alpha^{*}\right) f\left(h_{f}^{*}, h_{m}\right)}{\partial h_{m}}-\frac{\partial \eta_{m} c\left(\alpha^{*}, h_{f}^{*}, h_{m}\right)}{\partial h_{m}} \\
& =\left(\beta+\alpha^{*}\right) f_{2}\left(h_{f}^{*}, h_{m}\right)-\eta_{m} c_{3}\left(\alpha^{*}, h_{f}^{*}, h_{m}\right)>0
\end{aligned}
$$

by the Envelop Theorem. Since

$$
\frac{\partial^{2} U^{*}}{\partial h_{m} \partial \alpha}=\alpha^{*} f_{2}\left(h_{f}^{*}, h_{m}\right)-\eta_{m} c_{31}\left(\alpha^{*}, h_{f}^{*}, h_{m}\right)>0
$$


we have

$$
\left.\frac{\partial U^{*}}{\partial h_{m}}\right|_{\left(\alpha^{*}, h_{f}^{*}\right)}>\left.\frac{\partial U^{*}}{\partial h_{m}}\right|_{\left(\alpha^{* *}, h_{f}^{*}\right)}>\partial\left(\beta+\alpha^{* *}\right) f\left(h_{f}^{*}, h_{m}\right) / \partial h_{m},
$$

where the first inequality is because $\alpha^{*}>\alpha^{* *}$, and the second inequality is because the second term of $\frac{\partial U^{*}}{\partial h_{m}}$ in $(8)$ is positive. ( $\left.i\right)$ If $h_{f}^{*}>h_{f}^{* *}$, then $\partial^{2}(\beta+\alpha) f\left(h_{f}, h_{m}\right) / \partial h_{m} \partial h_{f}=$ $f_{12}\left(h_{f}, h_{m}\right)>0$ implies

$$
\partial\left(\beta+\alpha^{* *}\right) f\left(h_{f}^{*}, h_{m}\right) / \partial h_{m}>\partial\left(\beta+\alpha^{* *}\right) f\left(h_{f}^{* *}, h_{m}\right) / \partial h_{m}
$$

which combined with the inequality in (9) implies

$$
\left.\frac{\partial U^{*}}{\partial h_{m}}\right|_{\left(\alpha^{*}, h_{f}^{*}\right)}>\partial\left(\beta+\alpha^{* *}\right) f\left(h_{f}^{* *}, h_{m}\right) / \partial h_{m}
$$

and this leads to

$$
\partial \pi / \partial h_{m}=\frac{\partial U^{*}}{\partial h_{m}}-\partial\left(\beta+\alpha^{* *}\right) f\left(h_{f}^{* *}, h_{m}\right) / \partial h_{m}>0 .
$$

(ii) When $h_{f}^{*} \leq h_{f}^{* *}$ is the case, the result can be derived in a similar way due to

$$
\frac{\partial\left(\beta+\alpha^{* *}\right) f\left(h_{f}^{* *}, h_{m}\right)}{\partial h_{m}}<\frac{\partial\left(\beta+\alpha^{*}\right) f\left(h_{f}^{* *}, h_{m}\right)}{\partial h_{m}}-\frac{\partial \eta_{m} c\left(\alpha^{*}, h_{f}^{*}, h_{m}\right)}{\partial h_{m}}<\left.\frac{\partial U^{*}}{\partial h_{m}}\right|_{\left(\alpha^{*}, h_{f}^{*}\right)}
$$

where the first inequality holds because of $\alpha^{* *}<\alpha^{*}$ and $-\partial \eta_{m} c\left(\alpha^{*}, h_{f}^{*}, h_{m}\right) / \partial h_{m}>0$, while the second inequality holds because $\left(\alpha^{*}, h_{f}^{*}\right)$ is the optimal choice to maximize $U^{*}$ than $\left(\alpha^{*}, h_{f}^{* *}\right)$; comparing the first and the third terms we get $\partial \pi / \partial h_{m}>0$.

So the threshold $h_{p}^{\#}$ is uniquely determined by

$$
\pi=\left(\beta+\alpha^{*}\right) f\left(h_{f}^{*}, h_{m}\right)-\eta_{m} c\left(\alpha^{*}, h_{f}^{*}, h_{m}\right)-\left(\beta+\alpha^{* *}\left(h_{p}^{\#}\right)\right) f\left(h_{f}^{* *}\left(h_{p}^{\#}\right), h_{m}\right)=0 .
$$

Based on this identity, we get

$$
\begin{aligned}
\frac{\partial h_{p}^{\#}}{\partial h_{m}} & =-\frac{\partial \pi / \partial h_{m}}{\partial \pi / \partial h_{p}}>0 \\
\frac{\partial h_{p}^{\#}}{\partial \gamma} & =-\frac{\partial \pi / \partial \gamma}{\partial \pi / \partial h_{p}}=-\frac{f\left(h_{f}^{* *}, h_{m}\right) \partial \alpha^{* *} / \partial \gamma+\left(\beta+\alpha^{* *}\right) f_{1}\left(h_{f}^{* *}, h_{m}\right) \partial h_{f}^{* *} / \partial \gamma}{-\partial \pi / \partial h_{p}}<0, \\
\frac{\partial h_{p}^{\#}}{\partial \eta_{m}} & =-\frac{\partial \pi / \partial \eta_{m}}{\partial \pi / \partial h_{p}}=\frac{-c\left(\alpha^{*}, h_{f}^{*}, h_{m}\right)}{-\partial \pi / \partial h_{p}}<0 .
\end{aligned}
$$

The comparative statics for the threshold level $h_{m}^{\#}$ can be derived in a similar manner. 
Figure 1: Theoretical Predication on the Son's Optimal Choice of Matchmaking Method

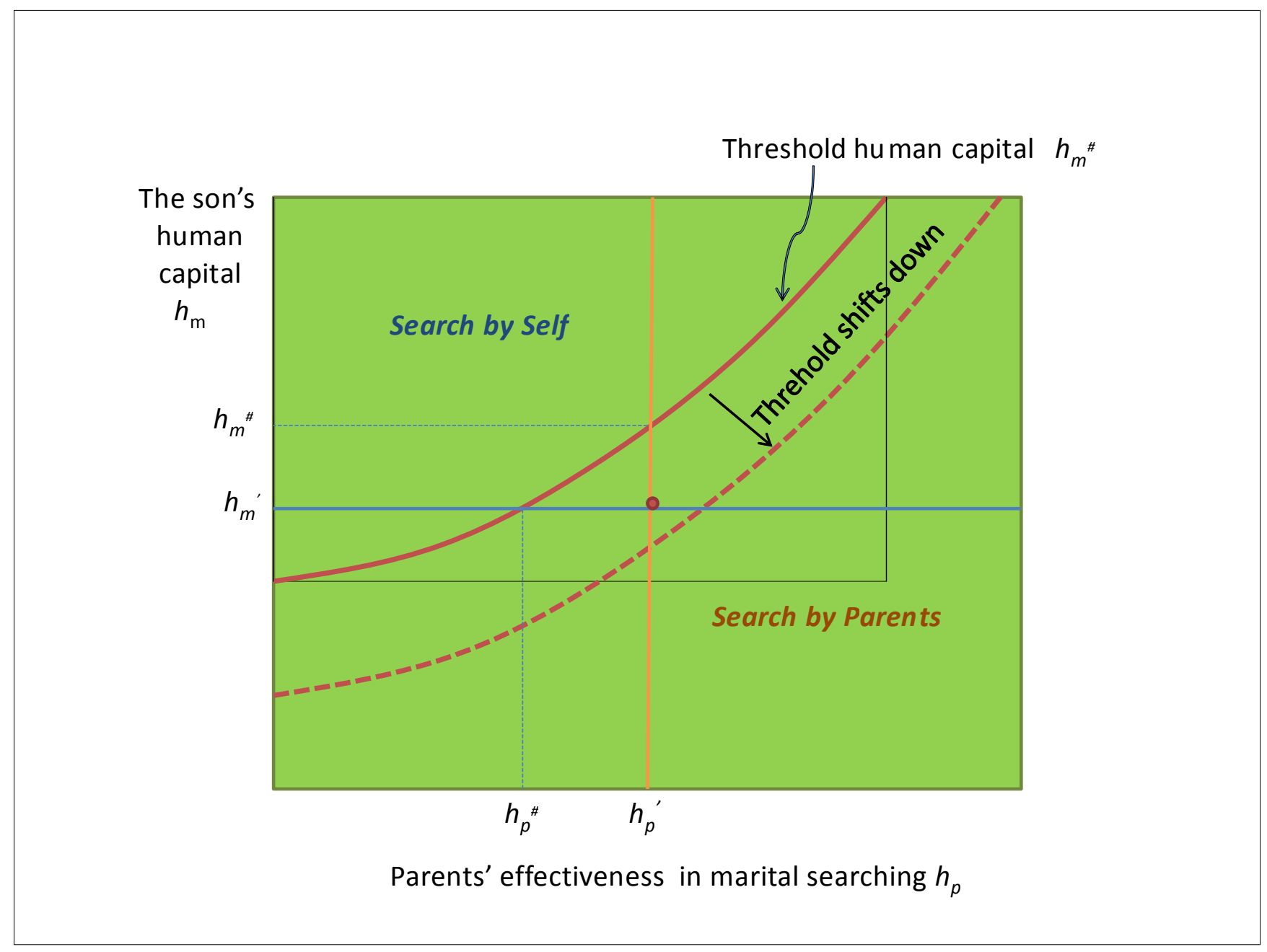


Table 1. Summary Statistics and Comparison by Status of Parental Matchmaking

\begin{tabular}{|c|c|c|c|c|c|c|c|c|c|}
\hline & \multicolumn{2}{|c|}{$\begin{array}{l}\text { Pooled } \\
\text { (1) }\end{array}$} & \multicolumn{2}{|c|}{$\begin{array}{c}\text { Parent } \\
\text { matched } \\
\text { (2) }\end{array}$} & \multicolumn{2}{|c|}{$\begin{array}{c}\text { Self } \\
\text { matched } \\
(3)\end{array}$} & \multicolumn{3}{|c|}{$\begin{array}{c}\text { Difference } \\
(4)=(2)-(3)\end{array}$} \\
\hline & Mean & S.D. & Mean & S.D. & Mean & S.D. & Diff & S.D. & t-stat \\
\hline Parent Matched & 0.338 & 0.473 & & & & & & & \\
\hline Parent Matched Norm & 0.351 & 0.188 & 0.450 & 0.163 & 0.300 & 0.179 & 0.149 & 0.005 & 32.366 \\
\hline \multicolumn{10}{|l|}{ Couple outcomes } \\
\hline Harmony & 1.015 & 0.715 & 0.968 & 0.707 & 1.038 & 0.718 & -0.070 & 0.019 & 3.600 \\
\hline No conflicts & 0.253 & 0.435 & 0.224 & 0.417 & 0.268 & 0.443 & -0.044 & 0.012 & 3.843 \\
\hline $\operatorname{Ln}($ Couple annual income $)$ & 8.752 & 1.195 & 8.226 & 1.031 & 9.020 & 1.183 & -0.795 & 0.030 & 26.379 \\
\hline Number of children & 1.646 & 1.025 & 1.895 & 1.075 & 1.518 & 0.974 & 0.376 & 0.027 & 14.039 \\
\hline Three or more children & 0.162 & 0.369 & 0.241 & 0.428 & 0.122 & 0.327 & 0.118 & 0.010 & 12.237 \\
\hline Having a boy & 0.676 & 0.468 & 0.753 & 0.431 & 0.637 & 0.481 & 0.117 & 0.012 & 9.446 \\
\hline \multicolumn{10}{|l|}{ Husband characteristics } \\
\hline Age & 34.892 & 6.291 & 34.556 & 6.366 & 35.064 & 6.246 & -0.508 & 0.167 & 3.041 \\
\hline Schooling & 8.718 & 3.218 & 7.677 & 3.153 & 9.249 & 3.120 & -1.572 & 0.083 & 18.903 \\
\hline Mother schooling & 2.196 & 3.163 & 1.445 & 2.559 & 2.580 & 3.367 & -1.134 & 0.083 & 13.701 \\
\hline Father schooling & 4.310 & 3.719 & 3.322 & 3.330 & 4.815 & 3.806 & -1.493 & 0.097 & 15.395 \\
\hline Communist Party member & 0.204 & 0.403 & 0.140 & 0.347 & 0.237 & 0.425 & -0.098 & 0.011 & 9.177 \\
\hline Age at first marriage & 24.874 & 3.490 & 23.811 & 3.306 & 25.417 & 3.457 & -1.606 & 0.090 & 17.742 \\
\hline Rural*First job was in TVEs & 0.061 & 0.240 & 0.067 & 0.251 & 0.058 & 0.235 & 0.009 & 0.006 & 1.384 \\
\hline Urban*First job was in SOEs & 0.169 & 0.375 & 0.079 & 0.270 & 0.215 & 0.411 & -0.136 & 0.010 & 13.828 \\
\hline $\begin{array}{l}\text { Belief in providing old age } \\
\text { support }\end{array}$ & 0.447 & 0.497 & 0.446 & 0.497 & 0.448 & 0.497 & -0.003 & 0.013 & 0.195 \\
\hline \multicolumn{10}{|l|}{$\underline{\text { Wife traits }}$} \\
\hline Wife schooling & 7.350 & 3.859 & 5.736 & 3.809 & 8.174 & 3.618 & -2.438 & 0.098 & 24.919 \\
\hline Wife work & 0.686 & 0.464 & 0.513 & 0.500 & 0.776 & 0.417 & -0.263 & 0.013 & 21.029 \\
\hline Ln(wife annual income) & 7.223 & 0.821 & 6.935 & 0.852 & 7.369 & 0.765 & -0.433 & 0.021 & 20.208 \\
\hline Wife submissiveness (total) & 1.036 & 0.882 & 1.232 & 0.901 & 0.937 & 0.855 & 0.295 & 0.023 & 12.651 \\
\hline Wife career unimportant & 0.184 & 0.387 & 0.232 & 0.422 & 0.159 & 0.366 & 0.073 & 0.010 & 7.103 \\
\hline No good male friend & 0.386 & 0.487 & 0.484 & 0.500 & 0.336 & 0.472 & 0.148 & 0.013 & 11.525 \\
\hline Cannot reject sex & 0.469 & 0.499 & 0.517 & 0.500 & 0.445 & 0.497 & 0.072 & 0.013 & 5.430 \\
\hline \multicolumn{10}{|l|}{ Township characteristics } \\
\hline Rural & 0.576 & 0.494 & 0.819 & 0.385 & 0.453 & 0.498 & 0.366 & 0.012 & 29.779 \\
\hline $\begin{array}{l}\mathrm{Ln}(\text { avg individual income at } \\
\text { township level) }\end{array}$ & 8.151 & 1.075 & 7.661 & 0.860 & 8.401 & 1.087 & -0.740 & 0.027 & 27.407 \\
\hline $\begin{array}{l}\text { Average years of schooling at } \\
\text { township level }\end{array}$ & 7.812 & 2.371 & 6.682 & 2.018 & 8.389 & 2.330 & -1.707 & 0.059 & 28.837 \\
\hline
\end{tabular}


Table 2. Assortative Matching and Social Norms

\begin{tabular}{lcc}
\hline & \multicolumn{2}{c}{$\begin{array}{c}\text { Correlation between } \\
\text { husband schooling and wife schooling }\end{array}$} \\
\hline Local parental matchmaking norm & $-0.481^{* * *}$ & $-0.395^{* *}$ \\
Average schooling for the region-cohort cell & $(0.079)$ & $(0.188)$ \\
& & 0.007 \\
Intercept & & $(0.014)$ \\
& $0.495^{* * *}$ & $0.410^{* *}$ \\
Number of observations & $(0.033)$ & $(0.172)$ \\
Adjusted R2 & 142 & 142 \\
\hline
\end{tabular}

Note: Unit of observation is province-urban-AgeCohort. Cohorts are classified by age: $<=22$, then $23-25,26-28, \ldots$, 50-52, 53-55, and 56-71. The few oldest cohorts cover a larger age span because of the limitations of cell sizes. * $\mathrm{p}<0.1, * * \mathrm{p}<0.05$, and $* * * \mathrm{p}<0.01$. 
Table 3. Determinants of Matchmaking Methods

\begin{tabular}{|c|c|c|c|c|}
\hline \multirow{3}{*}{ Rural } & \multicolumn{4}{|c|}{ Parent Matched } \\
\hline & $0.180 * * *$ & 0.024 & 0.054 & 0.063 \\
\hline & $(0.065)$ & $(0.069)$ & $(0.072)$ & $(0.074)$ \\
\hline \multicolumn{5}{|l|}{ Husband Characteristics } \\
\hline \multirow[t]{2}{*}{ Ln(age) } & $0.129 * * *$ & 0.038 & 0.036 & $(0.074)$ \\
\hline & $(0.040)$ & $(0.043)$ & $(0.044)$ & 0.032 \\
\hline \multirow[t]{2}{*}{ Schooling } & -0.005 & -0.005 & -0.005 & $(0.043)$ \\
\hline & $(0.004)$ & $(0.004)$ & $(0.004)$ & 0.002 \\
\hline \multirow[t]{2}{*}{ Mother schooling } & 0.001 & 0.000 & 0.001 & $(0.003)$ \\
\hline & $(0.003)$ & $(0.003)$ & $(0.003)$ & 0.000 \\
\hline \multirow[t]{2}{*}{ Father schooling } & -0.003 & -0.003 & -0.003 & $(0.002)$ \\
\hline & $(0.002)$ & $(0.002)$ & $(0.002)$ & -0.003 \\
\hline \multirow[t]{2}{*}{ Communist Party Member } & -0.007 & -0.017 & -0.019 & $(0.002)$ \\
\hline & $(0.015)$ & $(0.015)$ & $(0.016)$ & -0.020 \\
\hline \multirow[t]{2}{*}{ Being a Muslin } & 0.059 & 0.016 & 0.020 & 0.018 \\
\hline & $(0.045)$ & $(0.045)$ & $(0.045)$ & $(0.046)$ \\
\hline \multirow{2}{*}{ Being a Christian } & 0.022 & 0.038 & 0.036 & 0.036 \\
\hline & $(0.086)$ & $(0.085)$ & $(0.084)$ & $(0.084)$ \\
\hline \multirow[t]{2}{*}{ Being a Buddhist } & $0.169 * * *$ & 0.136 & 0.135 & 0.133 \\
\hline & $(0.063)$ & $(0.082)$ & $(0.082)$ & $(0.084)$ \\
\hline \multirow{2}{*}{ Korean ethnicity } & $0.228 * *$ & $0.175^{* *}$ & $0.172 * *$ & $0.175^{*}$ \\
\hline & $(0.089)$ & $(0.088)$ & $(0.086)$ & $(0.089)$ \\
\hline \multirow[t]{2}{*}{ Manchurian ethnicity } & $0.119^{*}$ & 0.058 & 0.060 & 0.060 \\
\hline & $(0.066)$ & $(0.065)$ & $(0.066)$ & $(0.066)$ \\
\hline \multicolumn{5}{|l|}{ Township characteristics } \\
\hline \multirow[t]{2}{*}{$\operatorname{Ln}$ (avg income per capita in the township) } & $-0.034 *$ & -0.018 & -0.017 & -0.016 \\
\hline & $(0.019)$ & $(0.017)$ & $(0.016)$ & $(0.016)$ \\
\hline \multirow[t]{2}{*}{ Average schooling in the township } & -0.014 & -0.008 & -0.007 & -0.007 \\
\hline & $(0.010)$ & $(0.011)$ & $(0.011)$ & $(0.011)$ \\
\hline \multicolumn{5}{|l|}{ Social norm and initial jobs } \\
\hline \multirow[t]{2}{*}{ Local parental matchmaking norm } & & $0.628 * * *$ & $0.596^{* * *}$ & $0.734 * * *$ \\
\hline & & $(0.145)$ & $(0.146)$ & $(0.157)$ \\
\hline \multirow[t]{2}{*}{ Local parental matchmaking norm*Schooling } & & & & -0.018 \\
\hline & & & & $(0.014)$ \\
\hline \multirow[t]{2}{*}{ Rural*First job was TVE } & & & $-0.060^{*}$ & $-0.057^{*}$ \\
\hline & & & $(0.031)$ & $(0.031)$ \\
\hline \multirow[t]{2}{*}{ Urban*First job was SOE } & & & 0.022 & 0.022 \\
\hline & & & $(0.014)$ & $(0.014)$ \\
\hline Number of observations / Adjusted R2 & $6,334 / 0.138$ & $6,334 / 0.147$ & $6,334 / 0.148$ & $6,334 / 0.148$ \\
\hline $\begin{array}{l}\text { P-value of (joint) significance of "social norm" (and } \\
\text { if applicable) and initial jobs }\end{array}$ & & 0.000 & 0.000 & 0.000 \\
\hline
\end{tabular}

Note. ${ }^{*} \mathrm{p}<0.1,{ }^{*} \mathrm{p}<0.05, * * * \mathrm{p}<0.01$. All columns control for Hui ethnicity and other minority ethnicity, and both are statistically insignificant. 
Table 4A. Parental Matchmaking, Love, and Money

\begin{tabular}{|c|c|c|c|c|c|c|c|c|}
\hline & \multicolumn{4}{|c|}{ Harmony } & \multicolumn{4}{|c|}{ Log (couple income) } \\
\hline & OLS & IV & IV & IV & OLS & IV & IV & IV \\
\hline Parent-matched & $\begin{array}{l}-0.049 * \\
(0.029)\end{array}$ & $\begin{array}{c}-1.189 * * * \\
(0.452)\end{array}$ & $\begin{array}{l}-1.151 * \\
(0.692)\end{array}$ & $\begin{array}{c}-1.192 * * * \\
(0.407)\end{array}$ & $\begin{array}{l}-0.025 \\
(0.019)\end{array}$ & $\begin{array}{l}-0.163 \\
(0.161)\end{array}$ & $\begin{array}{c}-1.155^{* *} \\
(0.514)\end{array}$ & $\begin{array}{l}-0.275^{*} \\
(0.157)\end{array}$ \\
\hline Ln(husband age) & $\begin{array}{c}0.135^{*} \\
(0.079)\end{array}$ & $\begin{array}{c}0.271 * * \\
(0.107)\end{array}$ & $\begin{array}{c}0.266^{* *} \\
(0.118)\end{array}$ & $\begin{array}{c}0.271 * * * \\
(0.104)\end{array}$ & $\begin{array}{c}0.172 * * * \\
(0.040)\end{array}$ & $\begin{array}{c}0.190 * * * \\
(0.048)\end{array}$ & $\begin{array}{c}0.321 * * * \\
(0.087)\end{array}$ & $\begin{array}{c}0.205^{* * *} \\
(0.048)\end{array}$ \\
\hline Husband schooling & $\begin{array}{c}0.001 \\
(0.004)\end{array}$ & $\begin{array}{l}-0.003 \\
(0.006)\end{array}$ & $\begin{array}{l}-0.003 \\
(0.006)\end{array}$ & $\begin{array}{l}-0.003 \\
(0.006)\end{array}$ & $\begin{array}{c}0.021 * * * \\
(0.005)\end{array}$ & $\begin{array}{c}0.020 * * * \\
(0.004)\end{array}$ & $\begin{array}{c}0.015 * * * \\
(0.004)\end{array}$ & $\begin{array}{c}0.019 * * * \\
(0.004)\end{array}$ \\
\hline Husband's mother schooling & $\begin{array}{c}0.000 \\
(0.004)\end{array}$ & $\begin{array}{c}0.000 \\
(0.006)\end{array}$ & $\begin{array}{c}0.000 \\
(0.006)\end{array}$ & $\begin{array}{c}0.000 \\
(0.006)\end{array}$ & $\begin{array}{c}0.000 \\
(0.003)\end{array}$ & $\begin{array}{c}0.000 \\
(0.003)\end{array}$ & $\begin{array}{c}0.001 \\
(0.004)\end{array}$ & $\begin{array}{c}0.000 \\
(0.003)\end{array}$ \\
\hline Husband's father schooling & $\begin{array}{l}-0.000 \\
(0.004)\end{array}$ & $\begin{array}{l}-0.003 \\
(0.005)\end{array}$ & $\begin{array}{l}-0.003 \\
(0.005)\end{array}$ & $\begin{array}{l}-0.003 \\
(0.005)\end{array}$ & $\begin{array}{c}0.004 \\
(0.002)\end{array}$ & $\begin{array}{c}0.003 \\
(0.002)\end{array}$ & $\begin{array}{l}-0.000 \\
(0.003)\end{array}$ & $\begin{array}{c}0.003 \\
(0.002)\end{array}$ \\
\hline $\begin{array}{l}\text { Husband is Communist Party } \\
\text { member }\end{array}$ & $\begin{array}{c}0.015 \\
(0.030)\end{array}$ & $\begin{array}{c}0.005 \\
(0.036)\end{array}$ & $\begin{array}{c}0.006 \\
(0.036)\end{array}$ & $\begin{array}{c}0.005 \\
(0.036)\end{array}$ & $\begin{array}{c}0.075^{* * *} \\
(0.012)\end{array}$ & $\begin{array}{c}0.074 * * * \\
(0.012)\end{array}$ & $\begin{array}{c}0.065^{* * *} \\
(0.021)\end{array}$ & $\begin{array}{c}0.073 * * * \\
(0.013)\end{array}$ \\
\hline Ln (township income per capita) & $\begin{array}{c}0.042 \\
(0.032)\end{array}$ & $\begin{array}{c}0.008 \\
(0.033)\end{array}$ & $\begin{array}{c}0.009 \\
(0.036)\end{array}$ & $\begin{array}{c}0.008 \\
(0.033)\end{array}$ & $\begin{array}{c}0.970 * * * \\
(0.011)\end{array}$ & $\begin{array}{c}0.966^{* * *} \\
(0.012)\end{array}$ & $\begin{array}{c}0.935 * * * \\
(0.031)\end{array}$ & $\begin{array}{c}0.962 * * * \\
(0.013)\end{array}$ \\
\hline Average township schooling & $\begin{array}{l}-0.026 \\
(0.022)\end{array}$ & $\begin{array}{c}-0.048 * * \\
(0.024)\end{array}$ & $\begin{array}{l}-0.047 \\
(0.029)\end{array}$ & $\begin{array}{c}-0.048 * * \\
(0.024)\end{array}$ & $\begin{array}{l}-0.005 \\
(0.007)\end{array}$ & $\begin{array}{l}-0.007 \\
(0.007)\end{array}$ & $\begin{array}{l}-0.020 \\
(0.014)\end{array}$ & $\begin{array}{l}-0.008 \\
(0.008)\end{array}$ \\
\hline $\begin{array}{l}\text { Husband's religion, ethnicity, and } \\
\text { current job type dummies } \\
\text { IVs } \\
\text { P-value for Hansen's J }\end{array}$ & yes & Norm & $\begin{array}{c}\text { yes } \\
\text { Job }_{0} \\
0.264\end{array}$ & $\begin{array}{c}\text { yes } \\
\text { Norm+ } \\
\text { Job }_{0} \\
0.534\end{array}$ & yes & $\begin{array}{c}\text { yes } \\
\text { Norm }\end{array}$ & $\begin{array}{l}\mathrm{Job}_{0} \\
0.092\end{array}$ & $\begin{array}{l}\text { yes } \\
\text { Norm+ } \\
\text { Job }_{0} \\
0.014\end{array}$ \\
\hline KP rk Wald F & & 21.69 & 4.58 & 9.33 & & 17.75 & 3.72 & 7.91 \\
\hline AR weak IV test, p-value & & 0.009 & 0.083 & 0.004 & & 0.318 & 0.003 & 0.006 \\
\hline $\begin{array}{l}\text { P-value, joint significance of current } \\
\text { job status dummies }\end{array}$ & 0.786 & 0.673 & 0.773 & 0.635 & 0.000 & 0.000 & 0.000 & 0.000 \\
\hline Number of observations & 6,050 & 6,050 & 6,050 & 6,050 & 6,334 & 6,334 & 6,334 & 6,334 \\
\hline Adjusted R2 & 0.015 & 0.015 & - & - & 0.848 & 0.848 & 0.686 & 0.849 \\
\hline
\end{tabular}

Note: $* \mathrm{p}<0.1, * * \mathrm{p}<0.05$, and $* * * \mathrm{p}<0.01$. White corrected standard errors clustered at the township level in parentheses. The IVs labelled "Job 0 " are defined as urban*the first job of the husband was in an SOE, and rural*the first job of the husband was in a TVE (i.e., township and village enterprises). Current job type includes 10 dummies: urban*the current job of the husband was in an SOE or a collective firm, a privately owned firm, a foreign firm, or other ownership types; rural*the current job of the husband was in household production, in farming, in household non-agricultural activities, in a TVE, in other activities.

These current job type dummies absorb the rural dummy. 
Table 4B. Parent Matchmaking, Love, and Money: Rural and Urban Areas Separated

\begin{tabular}{|c|c|c|c|c|}
\hline & \multicolumn{2}{|c|}{ Harmony } & \multicolumn{2}{|c|}{$\log ($ joint income $)$} \\
\hline & OLS & IV & OLS & IV \\
\hline \multirow[t]{2}{*}{ Parent-matched } & $-0.095 *$ & $-1.805 * *$ & -0.000 & $0.442 * *$ \\
\hline & $(0.049)$ & $(0.730)$ & $(0.015)$ & $(0.205)$ \\
\hline \multirow[t]{2}{*}{ Parent-matched*rural } & 0.065 & 0.746 & -0.034 & $-0.874 * * *$ \\
\hline & $(0.060)$ & $(0.738)$ & $(0.029)$ & $(0.219)$ \\
\hline \multirow[t]{2}{*}{ Ln (husband age) } & $0.135^{*}$ & $0.278 * * *$ & $0.172 * * *$ & $0.198 * * *$ \\
\hline & $(0.079)$ & $(0.103)$ & $(0.040)$ & $(0.051)$ \\
\hline \multirow[t]{2}{*}{ Husband schooling } & 0.001 & -0.003 & $0.021 * * *$ & $0.019 * * *$ \\
\hline & $(0.004)$ & $(0.006)$ & $(0.005)$ & $(0.004)$ \\
\hline \multirow[t]{2}{*}{ Husband's mother schooling } & 0.000 & 0.000 & 0.000 & 0.001 \\
\hline & $(0.004)$ & $(0.006)$ & $(0.003)$ & $(0.003)$ \\
\hline \multirow[t]{2}{*}{ Husband's father schooling } & -0.000 & -0.003 & 0.004 & 0.003 \\
\hline & $(0.004)$ & $(0.005)$ & $(0.002)$ & $(0.002)$ \\
\hline \multirow[t]{2}{*}{$\begin{array}{l}\text { Husband is Communist Party } \\
\text { member }\end{array}$} & 0.016 & 0.012 & $0.075 * * *$ & $0.066^{* * *}$ \\
\hline & $(0.030)$ & $(0.038)$ & $(0.012)$ & $(0.014)$ \\
\hline \multirow[t]{2}{*}{ Ln (township income per capita) } & 0.043 & 0.015 & $0.970 * * *$ & $0.955 * * *$ \\
\hline & $(0.032)$ & $(0.033)$ & $(0.011)$ & $(0.014)$ \\
\hline \multirow[t]{2}{*}{ Average township schooling } & -0.026 & $-0.044 *$ & -0.005 & -0.013 \\
\hline & $(0.023)$ & $(0.024)$ & $(0.007)$ & $(0.008)$ \\
\hline $\begin{array}{l}\text { Husband's religion, ethnicity, and } \\
\text { current job type dummies }\end{array}$ & Yes & Yes & Yes & Yes \\
\hline IVs & & Norm, Norm*rural, Job ${ }_{0}$ & & Norm, Norm*rural, Job ${ }_{0}$ \\
\hline P-value for Hansen's J & & 0.795 & & 0.102 \\
\hline Number of observations & 6,050 & 6,050 & 6,334 & 6,334 \\
\hline Adjusted R2 & 0.015 & - & 0.858 & 0.835 \\
\hline
\end{tabular}


Table 5. Parent Matchmaking and Wife Schooling

\begin{tabular}{|c|c|c|c|c|}
\hline & \multicolumn{2}{|c|}{ Wife Schooling } & \multicolumn{2}{|c|}{ Wife Schooling } \\
\hline & OLS & IV & OLS & IV \\
\hline Parent-matched & $\begin{array}{c}-0.453 * * * \\
(0.077)\end{array}$ & $\begin{array}{c}-3.510 * * \\
(1.408)\end{array}$ & $\begin{array}{l}-0.055 \\
(0.271)\end{array}$ & $\begin{array}{c}-2.270 * * \\
(1.084)\end{array}$ \\
\hline Parent-matched*Husband schooling & & & $\begin{array}{l}-0.049 * \\
(0.029)\end{array}$ & $\begin{array}{l}-0.138 * \\
(0.077)\end{array}$ \\
\hline Ln(husband age) & $\begin{array}{c}-3.653 * * * \\
(0.352)\end{array}$ & $\begin{array}{c}-3.252 * * * \\
(0.341)\end{array}$ & $\begin{array}{c}-3.664 * * * \\
(0.352)\end{array}$ & $\begin{array}{c}-3.298 * * * \\
(0.328)\end{array}$ \\
\hline Husband schooling & $\begin{array}{c}0.250 * * * \\
(0.022)\end{array}$ & $\begin{array}{c}0.234 * * * \\
(0.021)\end{array}$ & $\begin{array}{c}0.268^{* * *} \\
(0.020)\end{array}$ & $\begin{array}{c}0.286 * * * \\
(0.028)\end{array}$ \\
\hline Husband's mother schooling & $\begin{array}{l}0.029 * \\
(0.015)\end{array}$ & $\begin{array}{c}0.031 * * \\
(0.015)\end{array}$ & $\begin{array}{l}0.027^{*} \\
(0.015)\end{array}$ & $\begin{array}{l}0.026^{*} \\
(0.015)\end{array}$ \\
\hline Husband's father schooling & $\begin{array}{c}0.028 * * \\
(0.011)\end{array}$ & $\begin{array}{c}0.019 \\
(0.014)\end{array}$ & $\begin{array}{c}0.029 * * \\
(0.011)\end{array}$ & $\begin{array}{c}0.021 \\
(0.013)\end{array}$ \\
\hline Husband is Communist Party member & $\begin{array}{c}0.261 * * * \\
(0.100)\end{array}$ & $\begin{array}{c}0.233 * * \\
(0.103)\end{array}$ & $\begin{array}{c}0.256^{* *} \\
(0.100)\end{array}$ & $\begin{array}{l}0.220 * * \\
(0.104)\end{array}$ \\
\hline Ln(township income per capita) & $\begin{array}{c}0.020 \\
(0.086)\end{array}$ & $\begin{array}{l}-0.075 \\
(0.077)\end{array}$ & $\begin{array}{c}0.022 \\
(0.087)\end{array}$ & $\begin{array}{l}-0.064 \\
(0.076)\end{array}$ \\
\hline Average township schooling & $\begin{array}{c}0.909^{* * * *} \\
(0.069)\end{array}$ & $\begin{array}{c}0.868 * * * \\
(0.068)\end{array}$ & $\begin{array}{c}0.909^{* * * *} \\
(0.069)\end{array}$ & $\begin{array}{c}0.870 * * * \\
(0.069)\end{array}$ \\
\hline $\begin{array}{l}\text { Husband's religion, ethnicity, and current } \\
\text { job type dummies }\end{array}$ & yes & yes & yes & yes \\
\hline IVs & & Norm $+\mathrm{Job}_{0}$ & & Norm $+\mathrm{Job}_{0}$ \\
\hline P-value for Hansen's J & & 0.022 & & 0.322 \\
\hline Number of observations & 6,334 & 6,334 & 6,334 & 6,334 \\
\hline Adjusted R2 & 0.538 & - & 0.539 & - \\
\hline
\end{tabular}

Note: $* \mathrm{p}<0.1, * * \mathrm{p}<0.05$, and $* * * \mathrm{p}<0.01$. White corrected standard errors clustered at the township level in parentheses. The rural dummy is absorbed by current job type dummies. 
Table 6. Parent Matchmaking, Wife Income and Wife Labor Market Participation

\begin{tabular}{|c|c|c|c|c|c|c|}
\hline & \multicolumn{2}{|c|}{$\log ($ wife annual income) } & \multicolumn{2}{|c|}{ Wife labor participation } & \multicolumn{2}{|c|}{$\begin{array}{l}\text { Wife labor participation: } \\
\text { alternative definition }\end{array}$} \\
\hline & OLS & IV & OLS/ & IV & OLS & IV \\
\hline Parent-matched & $\begin{array}{c}-0.072 * * \\
(0.031)\end{array}$ & $\begin{array}{c}-3.562 * * * \\
(0.902)\end{array}$ & $\begin{array}{c}-0.047 * * * \\
(0.014)\end{array}$ & $\begin{array}{c}-1.010 * * * \\
(0.323)\end{array}$ & $\begin{array}{l}-0.031 * \\
(0.016)\end{array}$ & $\begin{array}{c}-1.040 * * * \\
(0.280)\end{array}$ \\
\hline Ln(husband age) & $\begin{array}{c}0.678 * * * \\
(0.100)\end{array}$ & $\begin{array}{c}1.104 * * * \\
(0.195)\end{array}$ & $\begin{array}{c}0.222 * * * \\
(0.047)\end{array}$ & $\begin{array}{c}0.353 * * * \\
(0.074)\end{array}$ & $\begin{array}{c}0.122^{* * *} \\
(0.031)\end{array}$ & $\begin{array}{c}0.255^{* * * *} \\
(0.064)\end{array}$ \\
\hline Husband schooling & $\begin{array}{c}0.021 * * * \\
(0.005)\end{array}$ & $\begin{array}{c}0.002 \\
(0.012)\end{array}$ & $\begin{array}{c}0.008 * * * \\
(0.002)\end{array}$ & $\begin{array}{c}0.003 \\
(0.004)\end{array}$ & $\begin{array}{l}0.007 * * \\
(0.003)\end{array}$ & $\begin{array}{c}0.001 \\
(0.003)\end{array}$ \\
\hline Husband's mother schooling & $\begin{array}{c}0.007 \\
(0.004)\end{array}$ & $\begin{array}{c}0.011 \\
(0.010)\end{array}$ & $\begin{array}{c}0.003 \\
(0.002)\end{array}$ & $\begin{array}{c}0.003 \\
(0.004)\end{array}$ & $\begin{array}{l}-0.000 \\
(0.002)\end{array}$ & $\begin{array}{c}0.001 \\
(0.003)\end{array}$ \\
\hline Husband's father schooling & $\begin{array}{c}0.009 * * * \\
(0.003)\end{array}$ & $\begin{array}{l}-0.003 \\
(0.009)\end{array}$ & $\begin{array}{l}0.004 * * \\
(0.002)\end{array}$ & $\begin{array}{c}0.000 \\
(0.003)\end{array}$ & $\begin{array}{l}0.003 * \\
(0.002)\end{array}$ & $\begin{array}{l}-0.000 \\
(0.003)\end{array}$ \\
\hline Husband is Communist Party member & $\begin{array}{l}-0.048^{*} \\
(0.026)\end{array}$ & $\begin{array}{l}-0.096 * \\
(0.055)\end{array}$ & $\begin{array}{c}0.002 \\
(0.014)\end{array}$ & $\begin{array}{l}-0.011 \\
(0.022)\end{array}$ & $\begin{array}{l}-0.007 \\
(0.009)\end{array}$ & $\begin{array}{l}-0.016 \\
(0.019)\end{array}$ \\
\hline Ln(township income per capita) & $\begin{array}{c}0.315^{* * *} \\
(0.088)\end{array}$ & $\begin{array}{l}0.211 * * * \\
(0.076)\end{array}$ & $\begin{array}{c}0.116 * * * \\
(0.035)\end{array}$ & $\begin{array}{l}0.087 * * * \\
(0.028)\end{array}$ & $\begin{array}{c}0.100 * * * \\
(0.021)\end{array}$ & $\begin{array}{c}0.069 * * * \\
(0.019)\end{array}$ \\
\hline Average township schooling & $\begin{array}{l}0.057 * \\
(0.034)\end{array}$ & $\begin{array}{c}0.013 \\
(0.047)\end{array}$ & $\begin{array}{c}0.027 \\
(0.017) \\
\end{array}$ & $\begin{array}{c}0.013 \\
(0.019)\end{array}$ & $\begin{array}{c}0.037 * * * \\
(0.012)\end{array}$ & $\begin{array}{c}0.023 \\
(0.014)\end{array}$ \\
\hline $\begin{array}{l}\text { Husband's religion, ethnicity, and } \\
\text { current job type dummies }\end{array}$ & yes & yes & yes & yes & yes & yes \\
\hline IVs & & Norm $+\mathrm{Job}_{0}$ & & Norm $+\mathrm{Job}_{0}$ & & Norm $+\mathrm{Job}_{0}$ \\
\hline P-value for Hansen's J & & 0.322 & & 0.339 & & 0.443 \\
\hline Number of observations & 6,154 & 6,154 & 5,663 & 5,663 & 6,334 & 6,334 \\
\hline Adjusted R2 & 0.400 & & 0.553 & & 0.217 & \\
\hline
\end{tabular}

Note: $* \mathrm{p}<0.1, * * \mathrm{p}<0.05$, and $* * * \mathrm{p}<0.01$. White corrected standard errors clustered at the township level in parentheses. The rural dummy is absorbed by current job type dummies. 
Table 7. Parent Matchmaking and Wife Submissiveness

\begin{tabular}{|c|c|c|c|c|c|c|c|c|}
\hline & \multicolumn{2}{|c|}{$\begin{array}{l}\text { Wife Submissiveness } \\
\text { (overall) }\end{array}$} & \multicolumn{2}{|c|}{$\begin{array}{l}\text { Wife Career Not } \\
\text { Important }\end{array}$} & \multicolumn{2}{|c|}{ No Good Male Friend } & \multicolumn{2}{|c|}{ Cannot Reject Sex } \\
\hline & OLS & IV & OLS & IV & OLS & IV & OLS & IV \\
\hline \multirow[t]{2}{*}{ Parent-matched } & $0.059 *$ & $1.982 * * *$ & 0.007 & $0.610 * * *$ & $0.050 * * *$ & $1.026^{* * *}$ & -0.000 & 0.358 \\
\hline & $(0.031)$ & $(0.674)$ & $(0.016)$ & $(0.212)$ & $(0.018)$ & $(0.367)$ & $(0.015)$ & $(0.275)$ \\
\hline \multirow[t]{2}{*}{ Ln(husband age) } & 0.084 & -0.160 & 0.008 & -0.071 & 0.008 & -0.122 & 0.056 & 0.010 \\
\hline & $(0.092)$ & $(0.137)$ & $(0.032)$ & $(0.047)$ & $(0.056)$ & $(0.081)$ & $(0.048)$ & $(0.067)$ \\
\hline \multirow[t]{2}{*}{ Husband schooling } & -0.007 & 0.003 & -0.002 & 0.001 & -0.004 & 0.002 & -0.002 & 0.001 \\
\hline & $(0.006)$ & $(0.014)$ & $(0.002)$ & $(0.004)$ & $(0.003)$ & $(0.006)$ & $(0.004)$ & $(0.005)$ \\
\hline \multirow[t]{2}{*}{ Husband's mother schooling } & -0.006 & -0.008 & $0.003 *$ & 0.003 & $-0.008 * * *$ & $-0.009 * *$ & -0.002 & -0.002 \\
\hline & $(0.004)$ & $(0.007)$ & $(0.002)$ & $(0.002)$ & $(0.003)$ & $(0.004)$ & $(0.003)$ & $(0.003)$ \\
\hline \multirow[t]{2}{*}{ Husband's father schooling } & $-0.009 * *$ & -0.002 & $-0.005 * * *$ & -0.003 & -0.002 & 0.002 & -0.003 & -0.001 \\
\hline & $(0.004)$ & $(0.006)$ & $(0.002)$ & $(0.002)$ & $(0.002)$ & $(0.003)$ & $(0.002)$ & $(0.003)$ \\
\hline \multirow[t]{2}{*}{ Husband is Communist party member } & 0.031 & 0.049 & 0.012 & 0.018 & $0.050 * * *$ & $0.059 * *$ & $-0.027 *$ & -0.023 \\
\hline & $(0.027)$ & $(0.044)$ & $(0.012)$ & $(0.016)$ & $(0.016)$ & $(0.024)$ & $(0.015)$ & $(0.016)$ \\
\hline \multirow[t]{2}{*}{ Ln (township income per capita) } & $-0.132 * * *$ & $-0.079 *$ & $-0.036 * * *$ & -0.018 & $-0.042 *$ & -0.014 & $-0.049 * *$ & $-0.039 *$ \\
\hline & $(0.044)$ & $(0.045)$ & $(0.013)$ & $(0.016)$ & $(0.023)$ & $(0.024)$ & $(0.022)$ & $(0.021)$ \\
\hline \multirow[t]{2}{*}{ Average township schooling } & $-0.094 * * *$ & $-0.072 * * *$ & $-0.025 * *$ & -0.017 & -0.022 & -0.010 & $-0.042 * * *$ & $-0.038 * * *$ \\
\hline & $(0.028)$ & $(0.027)$ & $(0.010)$ & $(0.012)$ & $(0.015)$ & $(0.016)$ & $(0.015)$ & $(0.014)$ \\
\hline $\begin{array}{l}\text { Husband's religion, ethnicity, and } \\
\text { current job type dummies }\end{array}$ & Yes & Yes & Yes & Yes & Yes & Yes & Yes & Yes \\
\hline IVs & & Norm $+J_{o b}$ & & Norm $+\mathrm{Job}_{0}$ & & Norm $+\mathrm{Job}_{0}$ & & Norm $+\mathrm{Job}_{0}$ \\
\hline P-value for Hansen's J & & 0.502 & & 0.612 & & 0.279 & & 0.246 \\
\hline Number of observations & 6,256 & 6,256 & 6,334 & 6,334 & 6,298 & 6,298 & 6,268 & 6,268 \\
\hline Adjusted R2 & 0.135 & - & 0.056 & - & 0.082 & - & 0.042 & - \\
\hline
\end{tabular}

Note: $* \mathrm{p}<0.1, * * \mathrm{p}<0.05$, and $* * * \mathrm{p}<0.01$. White corrected standard errors clustered at the township level in parentheses. The rural dummy is absorbed by current job type dummies. 
Table 8. Parent Matchmaking and Fertility

\begin{tabular}{|c|c|c|c|c|c|c|}
\hline & \multicolumn{2}{|c|}{ Number of children } & \multicolumn{2}{|c|}{ Having $3+$ children } & \multicolumn{2}{|c|}{ Have any boys } \\
\hline & OLS & IV & OLS & IV & OLS & IV \\
\hline \multirow[t]{2}{*}{ Parent-matched } & $0.119 * * *$ & $4.718 * * *$ & $0.043 * * *$ & $0.843 * *$ & $0.027 * *$ & $0.536^{* *}$ \\
\hline & $(0.034)$ & $(1.257)$ & $(0.012)$ & $(0.338)$ & $(0.012)$ & $(0.219)$ \\
\hline \multirow[t]{2}{*}{ Ln(husband age) } & $1.042 * * *$ & 0.438 & $0.432 * * *$ & $0.327 * * *$ & $0.536^{* * *}$ & $0.470 * * *$ \\
\hline & $(0.209)$ & $(0.327)$ & $(0.064)$ & $(0.089)$ & $(0.042)$ & $(0.060)$ \\
\hline \multirow[t]{2}{*}{ Husband schooling } & 0.006 & $0.030^{*}$ & 0.001 & 0.006 & $0.005 * *$ & $0.008 * *$ \\
\hline & $(0.006)$ & $(0.018)$ & $(0.002)$ & $(0.004)$ & $(0.002)$ & $(0.003)$ \\
\hline \multirow[t]{2}{*}{ Husband's mother schooling } & -0.011 & -0.015 & -0.002 & -0.002 & $-0.005^{*}$ & $-0.005^{*}$ \\
\hline & $(0.008)$ & $(0.014)$ & $(0.003)$ & $(0.004)$ & $(0.003)$ & $(0.003)$ \\
\hline \multirow[t]{2}{*}{ Husband's father schooling } & -0.000 & 0.014 & 0.001 & 0.004 & 0.004 & $0.005 * *$ \\
\hline & $(0.006)$ & $(0.011)$ & $(0.002)$ & $(0.002)$ & $(0.002)$ & $(0.003)$ \\
\hline \multirow[t]{2}{*}{ Husband is Communist Party member } & $0.176 * * *$ & $0.219 * * *$ & $0.040 *$ & $0.047 * *$ & 0.016 & 0.021 \\
\hline & $(0.052)$ & $(0.081)$ & $(0.021)$ & $(0.022)$ & $(0.017)$ & $(0.017)$ \\
\hline \multirow[t]{2}{*}{ Ln(township income per capita) } & $0.623 * * *$ & $0.765 * * *$ & 0.018 & 0.043 & 0.015 & $0.031 *$ \\
\hline & $(0.107)$ & $(0.097)$ & $(0.029)$ & $(0.029)$ & $(0.017)$ & $(0.017)$ \\
\hline \multirow[t]{2}{*}{ Average township schooling } & $-0.212 * * *$ & $-0.149 * *$ & $-0.040 * * *$ & $-0.029 *$ & $-0.047 * * *$ & $-0.040 * * *$ \\
\hline & $(0.047)$ & $(0.067)$ & $(0.015)$ & $(0.017)$ & $(0.009)$ & $(0.012)$ \\
\hline Religion, ethnicity, current job type dummies & yes & yes & yes & yes & yes & yes \\
\hline IVs & & Norm $+\mathrm{Job}_{0}$ & & Norm $+\mathrm{Job}_{0}$ & & Norm $+\mathrm{Job}_{0}$ \\
\hline P-value for Hansen's J & & 0.413 & & 0.827 & & 0.082 \\
\hline Number of observations & 6,334 & 6,334 & 6,334 & 6,334 & 6,334 & 6,334 \\
\hline Adjusted R2 & 0.323 & - & 0.133 & - & 0.111 & - \\
\hline
\end{tabular}

Note: $* \mathrm{p}<0.1, * * \mathrm{p}<0.05$, and $* * * \mathrm{p}<0.01$. White corrected standard errors clustered at the township level in parentheses. The rural dummy is absorbed by current job type dummies. 
Table 9. Parent Matchmaking and Husband's Belief in Providing Old Age Support

\begin{tabular}{|c|c|c|}
\hline & \multicolumn{2}{|c|}{ Husband's belief in providing old age support } \\
\hline & OLS & IV \\
\hline \multirow[t]{2}{*}{ Parent-matched } & $0.042 * *$ & $0.805^{* * *}$ \\
\hline & $(0.017)$ & $(0.301)$ \\
\hline \multirow[t]{2}{*}{ Ln(husband age) } & $-0.121 * *$ & $-0.222 * * *$ \\
\hline & $(0.050)$ & $(0.072)$ \\
\hline \multirow[t]{2}{*}{ Husband schooling } & 0.005 & $0.009^{*}$ \\
\hline & $(0.003)$ & $(0.005)$ \\
\hline \multirow[t]{2}{*}{ Husband's mother schooling } & -0.002 & -0.002 \\
\hline & $(0.003)$ & $(0.004)$ \\
\hline \multirow[t]{2}{*}{ Husband's father schooling } & -0.001 & 0.002 \\
\hline & $(0.003)$ & $(0.003)$ \\
\hline \multirow[t]{2}{*}{ Husband is Communist Party member } & $0.046^{* *}$ & $0.054 * *$ \\
\hline & $(0.018)$ & $(0.022)$ \\
\hline \multirow[t]{2}{*}{ Ln (township income per capital) } & 0.034 & $0.058^{* *}$ \\
\hline & $(0.024)$ & $(0.027)$ \\
\hline \multirow[t]{2}{*}{ Average township schooling } & $0.031 * *$ & $0.042 * *$ \\
\hline & $(0.015)$ & $(0.018)$ \\
\hline Religion, ethnicity, current job type dummies & yes & yes \\
\hline IVs & & Norm $+\mathrm{Job}_{0}$ \\
\hline P-value for Hansen's J & & 0.521 \\
\hline Number of observations & 6,300 & 6,300 \\
\hline Adjusted R2 & 0.025 & - \\
\hline
\end{tabular}

